\title{
THE CLASS IS GREENER ON THE OTHER SIDE: HOW PRIVATE DONATIONS TO PUBLIC SCHOOLS PLAY INTO FAIR FUNDING
}

\author{
ABIGAIL MARGARET FRISCH $\dagger$
}

\begin{abstract}
It has been observed that forays into public education finance resemble Russian novels - "long, tedious, and everybody dies in the end." On any given day, dozens of news stories describe schools nationwide struggling to make ends meet. And, just as "each unhappy family is unhappy in its own way," each underfunded school is underfunded in its own complicated way. Funding for public education comes from many places, chief among them local property taxes, at least historically. States-which bear primary responsibility for administering their education systems-and private litigants have struggled for over sixty years to produce funding formulas that weaken the link between a community's wealth, as measured by property taxes, and the quality of its education.
\end{abstract}

Alongside that trend to develop more equitable public funding, another trend began to emerge, in the form of increased public school reliance on sophisticated private fundraising organizations. Studies show that these organizations are unequally distributed along socioeconomic lines, leading many to conclude that they foster exactly the sort of inequitable public school resources that states have been trying to stifle. Although there is not enough data to claim that this disrupts equitable funding efforts statewide or nationwide, these organizations continue to grow rapidly, and the existing anecdotal evidence of neighboring schools with dramatically different resources is troubling. Calls to prohibit such private donations are also troubling, however, as these donations are well intended and provide schools with necessary resources and community support.

Currently, no state-level regulations exist to provide guidance for how private donations might equitably exist within a publicly funded

Copyright (C) 2017 Abigail Margaret Frisch.

$\dagger$ Duke University School of Law, J.D. expected 2018. I am grateful to Professor Margaret H. Lemos for her guidance toward and within this topic, to Professor Jeremy Mullem and the Scholarly Writing Workshop for their input on early drafts, to the editors of the Duke Law Journal for their hard work, and to my in-famous family for their humor and encouragement. 
school system. This Note argues that it is time for state legislators to break this silence and proactively determine a statewide protocol for private donations that comports with their state's mission to provide a high quality public education to children from all socioeconomic backgrounds. In doing so, this Note emphasizes that it is critical to avoid characterizing private donations as inherently good or inherently bad because solutions permitting unlimited private donations are as undesirable as solutions that completely eliminate them. State legislators are equipped to find an appropriate point on that spectrum, one which protects the valuable goal of providing public education to all children equitably but does not discourage the valuable benefits of local community support for public education.

\section{INTRODUCTION}

It has been observed that forays into public education finance resemble Russian novels - "long, tedious, and everybody dies in the end." ${ }^{1}$ On any given day, dozens of news stories describe schools nationwide struggling to make ends meet. ${ }^{2}$ And, just as "each unhappy family is unhappy in its own way," 3 the funding scheme for each school is complicated in its own way. The United States has more than 14,000 school districts, ${ }^{4}$ containing roughly 98,000 schools, ${ }^{5}$ and each school receives a unique combination of federal, state, and local public funding, alongside funds it raises on its own. ${ }^{6}$ As Chief Justice Earl

1. Mark Yudof, School Finance Reform in Texas: The Edgewood Saga, 28 HARV. J. ON LEGIS. 499, 499 (1991). The same idea has also been stated somewhat less elegantly. See David Anderson, Parents Urge Harford School Officials To Reduce Class Sizes, Pay Teachers, BALT. SUN: AEGIS (Oct. 14, 2016), http://www.baltimoresun.com/news/maryland/harford/aegis/ph-agschool-budget-workshop-1019-20161014-story.html [https://perma.cc/VA8E-RV64] ("It creates an excessive amount of public drama and outcry and is an absolute sucking black hole of wasted time, energy and resources on everyone's part.").

2. An online news alert set to "(school OR education) AND (fund OR finance)" in fall 2016 generated roughly thirty articles per week. For an example of one of these articles, see Bryan Lowry, School Finance Case Poses Potential Fiscal Crisis for Kansas, WICHITA EAGLE (Sept. 17, 2016), http://www.kansas.com/news/politics-government/article102495432.html [https://perma.cc/ LM8Z-9CSF].

3. LeO TOlSTOY, ANNA KARENINA 1 (Wordsworth Eds. Ltd. 1995) (1877).

4. School Districts, U.S. CENSUS BUREAU (June 15, 2012), https://www.census.gov/did/ www/schooldistricts [https://perma.cc/HYK6-WF6H].

5. Nat'l Ctr. for Educ. Statistics, Table 216.10. Public Elementary and Secondary Schools, by Level of School: Selected Years, 1967-68 Through 2014-15, DiG. EdUC. STAT. (Oct. 2016), https://nces.ed.gov/programs/digest/d16/tables/dt16_216.10.asp?current=yes [https://perma.cc/ 32HS-9GN7].

6. Nat'l Ctr. for Educ. Statistics, Table 235.20. Revenues for Public Elementary and Secondary Schools, by Source of Funds and State or Jurisdiction: 2013-14, DIG. EDUC. STAT. (July 
Warren observed in 1954, "education is perhaps the most important function of state and local governments," as well as "the very foundation of good citizenship," such that "it is doubtful that any child may reasonably be expected to succeed in life if he is denied the opportunity of an education." "7 The economic resources dedicated to education are as significant as its societal importance-government revenue dedicated to public elementary and secondary schools was $\$ 623$ billion in 2013-14. ${ }^{8}$

Due in part to primary education's "highly localized," one-roomschoolhouse roots, and later affirmed by provisions in state constitutions, the ultimate legal responsibility for maintenance of public education systems is traditionally on state governments. ${ }^{9}$ States dedicate around 20 percent of their total budgets to education. ${ }^{10}$ But as shown below in Figure 1, schools receive roughly half of their funding from local sources, ${ }^{11}$ and the federal government is also a significant financial contributor. ${ }^{12}$ This makes for a plethora of unwieldly public school finance equations ${ }^{13}$ as well as "a lack of accountability,"14 culminating in a convoluted division of responsibility for schools' underfunding. ${ }^{15}$

2016), https://nces.ed.gov/programs/digest/d16/tables/dt16_235.20.asp?current=yes [https:// perma.cc/6LHX-CNVC] [hereinafter Table 235.20].

7. Brown v. Bd. of Educ., 347 U.S. 483, 493 (1954).

8. Table 235.20, supra note 6.

9. Claudia Goldin, A Brief History of Education in the United States 3-4, 22 (Nat'l Bureau of Econ. Research, Historical Paper No. 119, 1999), http://www.nber.org/papers/h0119.pdf [https://perma.cc/86ZB-DJLB]; see, e.g., Wilmore v. Annear, 65 P.2d 1433, 1437 (Colo. 1937) ("It is clear . . . that in so far as the public school fund is concerned the maintenance of public schools is a state rather than a local function."). For a discussion of the explicit language in state constitutions describing the state's responsibility regarding public education, see infra notes 5862 and accompanying text.

10. MARK G. YUdof ET Al., EduCATIONAl Policy AND THE LAW 806 (5th ed. 2012).

11. Id.

12. Nora E. Gordon, The Changing Federal Role in Education Finance and Governance, in HANDBOOK OF RESEARCH IN EDUCATION FINANCE AND POLICY 317, 325 (Helen F. Ladd \& Margaret E. Goertz eds., 2d ed. 2015).

13. This is particularly clear in North Carolina. An expert education research firm "met its match" when the state retained it to study its funding formulas. Matt Ellinwood, North Carolina's Illogical Neglect of Special Education, NC POL'Y WATCH (Apr. 13, 2012), http:/www.ncpolicywatch.com/2012/04/13/north-carolinas-illogical-neglect-of-special-education/ [https://perma.cc/B2VM-65GH]. It could not "even tell how many different formulas and pots of money are involved." Id.

14. Rachel R. Ostrander, School Funding: Inequality in District Funding and the Disparate Impact on Urban and Migrant School Children, 2015 BYU EDUC. \& L.J. 271, 274 (2015).

15. Several additional factors contribute to this blame game. It is difficult to hold schools accountable for spending, in part because schools are prone to last-minute, one-off items of 
Figure 1. Sources of Funding for Public Education (2012-13)

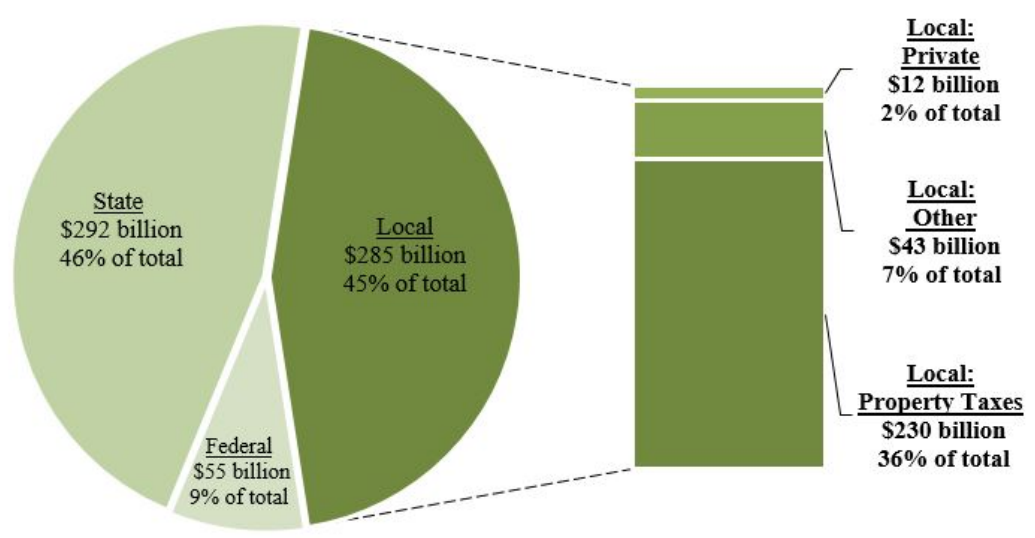

As demonstrated above in Figure 1, property taxes levied by local governments comprise the vast majority of local funding. ${ }^{16}$ Of particular interest here, though - about $\$ 12$ billion in local funding was from private sources, including "revenues from gifts, and tuition and fees from patrons." ${ }^{17}$ The increase in private sources of funding may not surprise parents with school-age children, as back-to-school shopping lists have crept beyond traditional pencils and rulers because of school funding cuts, and now hand sanitizer and facial tissue are typical on such lists. ${ }^{18}$ But, Kleenex boxes are only the beginning of

income and expense. This makes it difficult to track finances in the first place, and to communicate with the district and the state about those finances. Making matters worse, if a school does not trust the district, the school may have incentive to be less forthcoming about receiving extra spending money, fearing the district will supply less public funding next year. See Faith E. Crampton \& Paul Bauman, Educational Entrepreneurship: A New Challenge to Fiscal Equity?, 28 EDUC. CONSIDERATIONS 53, 58 (2000) ("[T]he school principals interviewed acknowledged that they did not report all entrepreneurial revenues to the central office because, in part, they believed they were not required to do so but also because they feared that if the central office knew of the revenues they would be taken from the school.”); RON ZIMMER ET AL., PRIVATE Giving to Public Schools AND Districts in Los ANGEles COUNTY: A PILOT STUdy 40 (2001), http://www.rand.org/pubs/monograph_reports/MR1429.html [https://perma.cc/XDY526EX] ("However, the schools in general were not well informed about district activities... . [O]nly four of the ten schools in [the] sample cited any district role in their fund-raising efforts, suggesting a lack of communication between some districts and schools.").

16. Property taxes make up 81 percent of local funds, accounting for 36 percent of total funding. Table 235.20, supra note 6 .

17. This is about 4 percent of local revenues. $I d$. The remaining local revenues come from other uncategorized sources. Id.

18. See, e.g., NeOsho Sch. Dist., MASTer School Supply List (2016), https://www .neoshosd.org/cms/lib/MO01909813/Centricity/Domain/666/MasterSchoolSupplyList-17-18.pdf 
many communities' efforts to roll up their sleeves and take responsibility for offsetting trims to the public education budget.

For example, nearly twenty years ago, parents at New York City's P.S. 41 in Greenwich Village collected $\$ 46,000$ to prevent budget cuts from eliminating a fourth grade teacher. ${ }^{19}$ Rudy Crew, the chancellor of New York City's Department of Education, refused to accept the donation, reportedly fearing that "affluent parents might create a twotier system, paying for services that poorer schools could not afford." 20 Across town on the Upper East Side, P.S. 6 principal Carmen Fariña ${ }^{21}$ explained that she felt differently about such donations because her school received less public money per student than other schools and because she directed the funds toward school supplies, computers, and part-time extracurricular instructors, which benefitted the whole school rather than one class or grade. ${ }^{22}$ Thinking similarly, the parents at P.S. 41 probably anticipated their efforts being met with gratitude and relief-after all, how could supporting education be a bad thing?

As it turns out, any attempt to answer that question generates controversy. For the last half-century, states have been engaged in an uphill battle to "weaken the link between local property wealth and school spending." 23 Starting in the 1960s, litigants troubled by that correlation began to challenge the legality of public education finance

[https://perma.cc/9UBX-FDLL] (listing tissues, baby wipes, and sandwich- and snack-size zipper storage bags).

19. Anemona Hartocollis, Crew Rejects Parents' Money To Pay One Teacher's Salary, N.Y. TIMES (Sept. 23, 1997), http://www.nytimes.com/1997/09/23/nyregion/crew-rejects-parentsmoney-to-pay-one-teacher-s-salary.html [https://perma.cc/LC7Y-GCDU].

20. Id.

21. Carmen Fariña eventually became the chancellor of the New York City Department of Education. Alexander Nazaryan, Carmen Fariña, New York City's School Chief, and the Perils of School Reform, NEwsweEK (Aug. 10, 2016, 6:30 AM), http://www.newsweek.com/2016/ 08/19/charters-schools-nyc-488880.html [https://perma.cc/8RGJ-7R58].

22. Henry Goldman, Parents' Gift to a N.Y. Public School Raises Issues of Fairness: They Contributed \$46,000 to Keep a Teacher from Being Transferred. Then the Chancellor Stepped in., PHILA. INQUIRER, Sept. 26, 1997, at A03. Fariña was referring to "programs that give public money to struggling schools with low test scores." Id. And others contemporaneously commented that "[m]ore affluent schools are at a financial disadvantage compared with schools that do not qualify for Federal money for poor and disadvantaged students," asserting that "P.S. 41 received 18 percent, $\$ 700$, less per student for classroom instruction than the average elementary school in New York City." Hartocollis, supra note 19.

23. Therese J. McGuire, Leslie E. Papke \& Andrew Reschovsky, Local Funding of Schools: The Property Tax and Its Alternatives, in HANDBOOK OF RESEARCH IN EDUCATION FINANCE AND POLICY, supra note 12, at 376, 380. 
schemes, ${ }^{24}$ and as of 2014, forty-five states have faced such legal challenges. ${ }^{25}$ Achievement and funding gaps correlating with socioeconomic status persist, ${ }^{26}$ and litigants continue to bring suits against state funding systems. Judges in these lawsuits usually order a restructuring of the state's education spending formula, which generally appears to result in more spending on education and a more equal distribution of that spending, although inconsistent datagathering methodology makes it difficult to generalize. ${ }^{27}$ For some states, however, efforts to equalize funding have backfired and resulted in a "leveling down" of expenditures. ${ }^{28}$ The most notable example is California, which ranked fifth in the nation for education expenditures per pupil in the 1980s but, following equalizing efforts and an economic recession, California's spending had fallen to forty-second by $1995 .{ }^{29}$

24. San Antonio Indep. Sch. Dist. v. Rodriguez, 411 U.S. 1, 8 (1973) (“[G]rowing disparities in population and taxable property between districts were responsible in part for increasingly notable differences in levels of local expenditure for education.").

25. Sean P. Corcoran \& William N. Evans, Equity, Adequacy, and the Evolving State Role in Education Finance, in HANDBOOK OF RESEARCH IN EDUCATION FinANCE AND POLICY, supra note 12 , at $353,355,367$.

26. NATASHA USHOMIRSKY \& DAVID WILliAMS, FUNDING GAPS 2015: TOO MANY STATES STILL SPEND LESS ON EdUCATING STUdENTS WHO NeEd THE Most 4 (2015).

27. Corcoran \& Evans, supra note 25, at 367 ("[S]tates affected by court-mandated finance reforms have increased expenditures and reduced interdistrict disparities. ..."). Additionally, some state legislatures initiated reform without a court order. McGuire, supra note 23, at 380. But see Christopher Berry, The Impact of School Finance Judgments on State Fiscal Policy, in SCHOOL Money TRIALs: THE LEgal PuRsuit of EduCATIONAL AdEQUACY 213, 233 (Martin R. West \& Paul E. Peterson eds., 2007) (finding "substantively small and statistically insignificant effects of school finance judgments," notwithstanding general findings of "an increase in the state's share of education funding and a modest (perhaps 16 percent) decline in spending inequality related to school finance judgments").

28. "Leveling down" is defined as "a reduction in spending disparities accomplished by reducing spending at the top of the distribution, either absolutely or relative to what it would have been in the absence of the reform." Corcoran \& Evans, supra note 25, at 360. Critics argue that this option eliminates the possibility for any school to achieve academic excellence. The concept can be illustrated using an excerpt from a dystopian short story:

The year was 2081 , and everybody was finally equal. They weren't only equal before God and the law. They were equal every which way. Nobody was smarter than anybody else. Nobody was better looking than anybody else. Nobody was stronger or quicker than anybody else. All this equality was due to the 211th, 212th, and 213th Amendments to the Constitution, and to the unceasing vigilance of agents of the United States Handicapper General.

Tristan L. Duncan, (Handi-)Capping Equality and Excellence: The Unconstitutionality of Spending Caps on Public Education, 45 Urb. LAW. 183, 183 (2013) (quoting KURT VonNEGUT, HARRISON BERGERON (1961)).

29. ZIMMER ET AL., supra note 15, at 9 (collecting studies "linking educational reform to the decline in spending per pupil" by suggesting that less local control means less "popular support for education," and less overall funding, and perhaps that centralized education funding places the education sector in direct competition "with other state expenditures for funds, and, as a 
As public funding fell, private fundraising grew. ${ }^{30}$ While schools have long looked outside the public sphere to tap additional sources of revenue,$^{31}$ the bake sales and car washes of yore are gradually being outpaced by sophisticated fundraising organizations. ${ }^{32}$ The organizations, termed "education support organizations" (ESOs) for purposes of this analysis, come in a variety of forms, include the traditional parent-teacher associations (PTAs) and alumni groups, as well as local education foundations (LEFs), which have grown in prominence since the $1980 \mathrm{~s} .{ }^{33}$ These organizations are typically tax-

result, the growth rate of spending per pupil will decrease over time" (citations omitted)); see also SUZANNE M. WILSON, CALIFORNIA DREAMING: REFORMING MATHEMATICS EDUCATION 138 (2003) (calculating, similarly, California's drop from fifth to forty-first); Corcoran \& Evans, supra note 25, at 360 (noting that "more than half of California's 'leveling down'" has been attributed to the effects of education reform litigation, including a "collapse in expenditure growth" per student due to property tax limitations and "enrollment growth caused by immigration").

30. See Michael A. Rebell, Safeguarding the Right to a Sound Basic Education in Times of Fiscal Constraint, 75 ALB. L. REV. 1855, 1863 (2011) [hereinafter Rebell, Safeguarding] (observing "the unprecedented extent, depth, and durability of the current state budgetary difficulties" following the 2008 recession); see also Natalie Gomez-Velez, Common Core State Standards and Philanthrocapitalism: Can Public Law Norms Manage Private Wealth's Influence on Public Education Policymaking?, 2016 MiCH. ST. L. REV. 161, 176 (2016) ("The Great Recession of 2008 impacted state school budgets across the country, causing states to force cuts and seek funding support wherever they could find it.").

31. See John C. Pijanowski \& Dr. David H. Monk, Alternative School Revenue Sources: There Are Many Fish in the Sea, SCH. Bus. AFF., July 1996, at 4 ("The resulting fiscal strain has prompted efforts in recent years to identify and draw upon alternate, and often non-traditional, sources of revenue."). See generally Michael F. Addonizio, Private Funds for Public Schools, 74 CLEARING HOUSE 70 (2000) (noting a history of schools engaging in direct fundraising as well as indirect fundraising such as leasing school facilities).

32. Ashlyn Aiko Nelson \& Beth Gazley, The Rise of School-Supporting Nonprofits, 9 EDUC. FIN. \& POL'Y 541, 552, 563 (2014) (“[C]ommunities depend increasingly on philanthropic revenue to support public education."). Although Professors Nelson and Gazley exclude local education fund ("LEF") information from the group of organizations they analyze, the broader social and quantitative trends regarding private fundraising apply with equal force to LEFs. While it is admittedly difficult to draw the line between small- and large-scale private interventions against public budget cuts, LEFs are included in this analysis because they have grown out of the same trends to collect many small, local donations, rather than large-scale philanthropic grants from individuals or corporations. Such larger grants are not considered for the purposes of this Note. For a brief discussion of some concerns regarding these larger grants, see infra note 41.

33. Rob Reich, Philanthropy and Its Uneasy Relation to Inequality, in TAKING

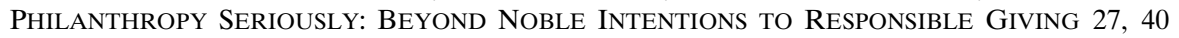
(William Damon \& Susan Verducci eds., 2006) [hereinafter Reich, Philanthropy]. See generally Elaine Simon, Jolley Bruce Christman, Tracey Hartmann \& Diane Brown, Research for Action, CRAfTing a Civic Stage for Public Education Reform: UNDERSTANDING THE WORK AND ACCOMPLISHMENTS OF LOCAL EDUCATION FUNDS 6 (2005), https://www.researchforaction.org/publications/crafting-a-civic-stage-for-public-educationreform-understanding-the-work-and-accomplishments-of-local-education-funds 
exempt 501(c)(3) organizations per the Internal Revenue Service (IRS). ${ }^{34}$

There is plenty of anecdotal evidence suggesting that private donations have exacerbated existing inequalities ${ }^{35}$ in funding for public schools, ${ }^{36}$ but it is not yet clear whether donations result in quantifiably significant differences in funding. ${ }^{37}$ Early studies indicated that private fundraising could never make a significant difference relative to the gargantuan public education budget, but since that time ESOs have grown expansively and continue to do so. ${ }^{38}$ At any rate, studies show that ESOs are more frequently associated with communities of relatively higher socioeconomic status. ${ }^{39}$ Schools with ESOs can more easily afford "class-size reductions, librarians, art and music teachers, and Smart technology in every classroom" than schools without ESOs. ${ }^{40}$ Thus, ESOs work in the opposite direction of states' efforts to weaken the link between socioeconomic status and quality of education. $^{41}$

[https://perma.cc/8YRK-5AQV] (providing an overview of the "roles and accomplishments of LEFs as they pertain to public education reform").

34. Linda M. Lampkin \& David D. Stern, Who Helps Public Schools: A Report on Local Education Funds, Urb. Inst. 5 (Nov. 2003), https://www.urban.org/sites/default/files/publication/ 59511/410915-Who-Helps-Public-Schools [https://perma.cc/VW6N-DD39].

35. USHOMIRSKY \& WILLIAMS, supra note 26 , at 8 . In 17 states, however, "high-poverty districts receive substantially (at least 5 percent) more in state and local funds than low-poverty districts." Id. at 4.

36. See, e.g., Rob Reich, Not Very Giving, N.Y. TIMES (Sept. 4, 2013), http://www.nytimes.com/2013/09/05/opinion/not-very-giving.html [https://perma.cc/W42B-QK72] [hereinafter Reich, Not Very Giving] ("Private giving to public schools widens the gap between rich and poor. It exacerbates inequalities in financing.").

37. Nelson \& Gazley, supra note 32, at 559.

38. Id.

39. Id.

40. Reich, Not Very Giving, supra note 36.

41. Beyond the scope of this discussion, scholars have also presented concerns about the policy influence resulting from increased donations by large philanthropic organizations (structured as public-private partnerships, nongovernmental organizations, or venture capital groups), especially in the charter school context. See, e.g., Gomez-Velez, supra note 30, at 164 ("The role of philanthrocapitalists [like Bill Gates] in the Common Core process is a striking example of the degree to which a small number of wealthy individuals can play a prominent role in education policymaking."); Rob Reich, Repugnant to the Whole Idea of Democracy? On the Role of Foundations in Democratic Societies, 49 PS: POL. SCI. \& POL. 466, 468 (2016) [hereinafter Reich, Repugnant] (explaining the federal government subsidy resulting from two tax breaks: reduced tax liability for relatively wealthier donors, and usually tax exemption for the foundations themselves); Janelle Scott, The Politics of Venture Philanthropy in Charter School Policy and Advocacy, 23 EDUC. POL'Y 106, 115 (2009) (reflecting on the concept of education as an economic commodity and the expectation of returns on philanthropic investments by saying "[g]rants become investments, programs are ventures"). 
This Note finds that states have not made meaningful legislative efforts to address the potentially inequitable consequences of private donations to public schools. ${ }^{42}$ It argues that state legislatures, in the midst of a fifty-year-old struggle to equalize school funding, are standing by as a thirty-year-old trend of unprecedented private fundraising works against those efforts. So, it is time for state legislatures to address private donations to public schools. The solution is not as simple as a flat ban on private donations because private donations go hand-in-hand with community engagement in education. As such, appropriate regulatory solutions must carefully balance the competing sets of values to calibrate a regime that avoids augmenting inequality without discouraging voluntary ${ }^{43}$ community support for primary and secondary public education. ${ }^{44}$ This Note argues that the most promising solutions accomplish this by allowing donations, calculating the point at which private donations would contribute to existing inequalities and redistributing donations beyond that threshold to communities less able to fundraise.

Part I supplies the legal backdrop for this discussion, first by recounting efforts to equalize public school funding through reform litigation and, second, by examining the current governmental and financial structure of public secondary education. Part II finds that states have not enacted legislation to address funding inequalities corresponding to private donations to public schools, and explains why it is an appropriate time to do so. Part III argues that while a free-forall is not an appropriate solution, neither is a flat ban on private donations. An appropriate solution must be a compromise that accounts for both sets of values. Part IV proposes that the most feasible solution is at the state level and then applies the balancing framework developed in Part III to several proposed regulatory schemes for private donations to public schools.

42. A survey of state statutes and regulations as of December 2016, see infra Appendix A, shows that while almost all states explicitly acknowledge private donations to public schools, and nearly half of the states have explicitly acknowledged fundraising efforts by ESO-type organizations, no state-level regulation or statute discusses the impact of such organizations on existing or potential funding disparities.

43. The consideration of property taxes is of limited scope in this Note, and relates to how limits on property taxes encouraged the growth of private donations, such that it is an appropriate topic for consideration by state legislatures.

44. Others also argue that vouchers, privatized schools, and charter schools undermine governmental efforts to make educational funding fair, but the following discussion pertains only to public primary and secondary schools. 


\section{BACKGROUND}

This Part provides a backdrop for this Note's analysis by reviewing the traditional structure of education finance and the history of education finance reform litigation over the last fifty years. This history is significant because the cases articulate the most deeply held, competing values that have committed states to providing fair funding for education and have continued to animate the debates about public education and finance. Next, this Part further examines the changes stemming from this litigation, which generally reduced local control over the structure of public education finance in attempts to make funding more fair. This Part then notes some of the unintended consequences of those changes, arising from a desire to maintain a degree of local control over educational resources and quality.

\section{A. Challenges to Traditional Public School Financing}

To carry out their constitutional mandates to provide public education, all states delegate limited authority to their school districts to collect funding. This vests authority in approximately 14,000 local governing bodies nationwide. ${ }^{45}$ Usually, this delegation is in the form of authority to levy taxes, but it also frequently extends to the authority to accept gifts, donations, and bequests. ${ }^{46}$

Although states now contribute most public funding for education, historically, local revenues provided the vast majority of funds. In the 1920s, local property taxes raised 83 percent of revenues for public education, and although federal and state funding increased following the Great Depression and World War II, local contributions still accounted for an average of 55.8 percent of public education funding between 1949 and $1969 .{ }^{47}$ The local property tax revenue available to a school depends on the product of the tax rate and property value; therefore, differences in local property values generate predictable peaks and valleys in the local revenues available to fund

45. School Districts, supra note 4 .

46. For an overview of statutes discussing other types of private donations to public education, see infra Appendix B.

47. The calculations that produced these results used data from U.S. Dept. of Educ., Nat'l Ctr. for Educ. Statistics, Table 152. Revenues for Public Elementary and Secondary Schools, by Source of Funds: Selected Years, 1919-20 Through 2002-03, DiG. EDUC. STAT. (2005), https:// nces.ed.gov/programs/digest/d05/tables/dt05_152.asp [https://perma.cc/L2SD-ZR6J]. 
schools. ${ }^{48}$ For example, in 1971, expenditures by New Jersey school districts displayed wide variation that corresponded to local property values. On average, its 578 school districts spent about $\$ 1000$ per student annually, but fourteen of its districts, in communities with relatively lower property valuations, spent less than $\$ 700$, and sixteen other districts, with relatively higher property valuations, spent over twice that amount at $\$ 1500 .{ }^{49}$

In the last fifty years, litigants seeking fair funding for education have resorted to several strategies, generally classified into three "waves": first, federal constitutional equity; second, state constitutional equity; third, state constitutional adequacy. ${ }^{50}$ These waves represent a loose chronological order, but the clearer and more important distinctions between the three waves are derived from the legal theories characterizing them..$^{51}$

Initially, litigants challenged the state funding systems that created these discrepancies in federal court on federal constitutional grounds, but the Supreme Court set an early outer boundary on federal judicial involvement in public education finance. In 1973, the Court held in San Antonio Independent School District v. Rodriguez ${ }^{52}$ that the Equal Protection Clause of the Constitution created no federal fundamental right to education, and that "individuals residing in property-poor school districts were not a suspect class." ${ }^{53}$ It reasoned that the state policy in Texas which led to "disparities in funding across school districts that resulted from differences in local taxable property wealth" survived rational basis scrutiny, and that "[t]he consideration and initiation of fundamental reforms with respect to state taxation and education are matters reserved for the legislative processes of the various States." ${ }^{\circ 4}$ Although this decision was criticized, and although

48. YUDOF ET AL., supra note 10, at 808 ("Local funding is a product of the tax rate and the property wealth in a district. Because some districts have more property wealth than others, they are able to raise more money at any given tax rate.").

49. Robinson v. Cahill, 287 A.2d 187, 197 (N.J. Super. Ct. Law Div. 1972).

50. Corcoran \& Evans, supra note 25, at 367.

51. See Christopher E. Adams, Comment, Is Economic Integration the Fourth Wave in School Finance Litigation?, 56 EMORY L.J. 1613, 1618-19 (2007) ("The wave metaphor is best used to characterize three types of funding challenges rather than three mutually exclusive periods.").

52. San Antonio Indep. Sch. Dist. v. Rodriguez, 411 U.S. 1 (1973).

53. Id. at 18; Bruce D. Baker \& Preston C. Green, Conceptions of Equity and Adequacy in School Finance, in HANDBOOK OF RESEARCH IN EDUCATION FINANCE AND POLICY, supra note 12, at 231, 234.

54. Rodriguez, 411 U.S. at 58; Baker \& Green, supra note 53, at 234. 
many continue to argue that strong federal judicial intervention is necessary to combat pervasive patterns of school funding inequality between states, ${ }^{55}$ Rodriguez appears to have shut the door on federal remedies for disparate funding. ${ }^{56}$

Disappointed federal court litigants seeking to hold somebody accountable started to turn to state constitutional law and began the state constitutional equity wave of litigation. ${ }^{57}$ Each state's constitution contains language requiring the legislature to provide a public school system of some kind. ${ }^{58}$ The exact language in each state's constitution varies, ${ }^{59}$ but the language is always abstract. For example, in Minnesota, "it is the duty of the legislature to establish a general and uniform system of public schools."60 Similarly, North Carolina's

55. Calls to recognize a federal fundamental right to education appear with relative frequency but, for better or for worse, do not appear to have gained much traction. A recent lawsuit out of Michigan, however, puts a new spin on this argument and argues for a fundamental right to literacy. Ryan Felton, Detroit Civil Rights Lawsuit Attempts To Assert a Constitutional Right to Literacy, GUARDiAn (Sept. 14, 2016 7:30 AM), https://www.theguardian.com/usnews/2016/sep/14/detroit-civil-rights-lawsuit-constitutional-literacy-education [https://perma.cc/53ZX-N68F].

56. Petrella v. Brownback, 787 F.3d 1242, 1261 (10th Cir. 2015) ("As in Rodriguez, we are loathe to disturb a matter better left to the states . . .."). Plaintiffs in Petrella attempted to pry open the door Rodriguez closed, using Rodriguez footnote 107, in which the Court left open the question of whether caps on local tax revenue are constitutional. Id. at 1262-63. Parents brought suit after a local public school faced budget cuts that would eliminate salaries for foreign language instructors, and a school official informed parents that Kansas law made it illegal for the community to raise the additional funds - about $\$ 25$ per household - to cover the shortfall. Id. at 1253-54; Duke Univ. Sch. of Law, Tristan L. Duncan T'84: When Failure Is Success in Constitutional Litigation, YouTuBE (Nov. 16, 2016), https://youtu.be/nBZdDx3kYDY [https:// perma.cc/N3P4-PKS2]; Telephone Interview with Tristan Duncan, Partner, Shook, Hardy \& Bacon (Nov. 8, 2016). The Tenth Circuit, however, was not persuaded and found that the Kansas law passed the rational basis test because it "promot[ed] equity in education funding," a legitimate government interest. Petrella, 787 F.3d at 1266-67. Incidentally, the Tenth Circuit concluded the parents did not have meritorious constitutional claims, in part because the parents could "donate as much money as they wish[ed]" to their school district, by sidestepping the taxation system. Id. at 1258 .

57. Joshua E. Weishart, Transcending Equality Versus Adequacy, 66 STAN. L. REV. 477, 50002 (2014).

58. This proposition has been contested. See, e.g., Jeffery Omar Usman, Good Enough for Government Work: The Interpretation of Positive Constitutional Rights in State Constitutions, 73 ALB. L. REV. 1459, 1465 n.3 (2010) ("It is periodically asserted in scholarly publications that the Mississippi Constitution is the sole exception in that it does not contain an education clause. That view is incorrect." (internal citations omitted)).

59. For excerpts of the various states' constitutions, see EMILY PARKER, EDUC. COMM'N OF the States, Constitutional Obligations for Public Education 5-22 (2016), https://www.ecs.org/ec-content/uploads/2016-Constitutional-obligations-for-public-education1.pdf [https://perma.cc/S82Z-LCX4].

60. MINN. CONST. art. XIII, § I. 
constitution provides for a "general and uniform system of free public schools ... wherein equal opportunities shall be provided for all students," 61 and California's, a "general diffusion of knowledge and intelligence being essential to the preservation of the rights and liberties of the people, the Legislature shall encourage by all suitable means the promotion of intellectual, scientific, moral, and agricultural improvement."62 This relative lack of specificity was a problem in federal court, where the Supreme Court feared that addressing public education finance would venture too far beyond federal enumerated powers. ${ }^{63}$ No such limitation existed in state courts, where plenary power was available to fill textual gaps. ${ }^{64}$

This wave of litigation, active from roughly 1973 to 1989 , was characterized by arguments about "equity." L5 Litigants argued that funding formulas tied to a district's property wealth, which resulted in dramatic differences in public education spending across districts, violated states' constitutional equal protection clauses ${ }^{66}$ and educational provisions referring to uniformity and equality ${ }^{67}$ Robinson v. Cahill $^{68}$ is a representative state constitutional equity case from this era. In Robinson, the Supreme Court of New Jersey held that the state had an "obligation to afford all pupils . . . a thorough and efficient system of education," which the legislature had not discharged, based on the abovementioned "discrepancies in dollar input per pupil." 69

61. N.C. CONST. art. IX, § 2 .

62. CAL. CONST. art. IX, § I.

63. See Scott R. Bauries, State Constitutions and Individual Rights: Conceptual Convergence in School Finance Litigation, 18 GEO. MASON L. REV. 301, 359 (2011) ("In the Federal Constitution, powers are granted broadly over policy areas . . . In contrast, state enumerations of power are unnecessary, as state legislatures already have all powers not ceded to the federal government or reserved to the people.").

64. See Usman, supra note 58, at 1477-78 (determining that the contrast between federal government's enumerated powers and state governments that "retain broad residual plenary authority" shapes state and federal constitutional decisions because "whereas the federal government can only act where constitutionally authorized to do so, state governments are generally free to act in any manner not prohibited by the United States Constitution or their state constitution"); see also Bauries, supra note 63, at 325 (noting that "most state constitutions provide a strong textual basis for an explicit Hohfeldian duty to provide for education").

65. William S. Koski \& Jesse Hahnel, The Past, Present, and Possible Futures of Educational Finance Reform Litigation, in HANDBOOK OF RESEARCH IN EDUCATION FINANCE AND POLICY, supra note 12 , at 41,46 .

66. William E. Thro, Judicial Analysis During the Third Wave of School Finance Litigation: The Massachusetts Decision as a Model, 35 B.C. L. REV. 597, 603 (1994).

67. Koski \& Hahnel, supra note 65 , at 46.

68. Robinson v. Cahill, 303 A.2d 273 (N.J. 1973).

69. Id. at 295. 
Determining the appropriate remedy in an equity suit, however, is difficult both in theory and in practice. ${ }^{70}$ In theoretical terms, equity litigants must define the equity they seek, and that definition usually implies some degree of inequality. Providing equal funding to all students may be facially equal, but because it costs more to educate students that face academic and socioeconomic challenges, ${ }^{71}$ equal funding is unlikely to furnish all children with equal educational opportunities. $^{72}$ On the other hand, providing more funding to compensate students for those disadvantages is challenging because it is, by definition, unequal. Alternatively, if equality simply means avoiding a direct connection between school funding and the property values in a community, that risks encouraging solutions that address the form, but not necessarily the substance, of funding inequalities. ${ }^{73}$

Theoretical quandaries aside, equity litigation presents practical challenges.$^{74}$ For example, New Jersey notoriously struggled to remedy its funding disparities, as the funding formula for its public schools bounced between the legislature and the courts for over thirty years. ${ }^{75}$ When adjudicating a constitutional challenge to its own state funding system, the North Carolina Supreme Court pointedly mentioned the "protracted litigation resulting in unworkable remedies" following New Jersey's equalization requirements, before concluding that the framers of North Carolina's state constitution "did not intend to set such an impractical or unattainable goal."${ }^{.76}$

70. Aaron Y. Tang, Broken Systems, Broken Duties: A New Theory for School Finance Litigation, 94 MARQ. L. REV. 1195, 1204-06 (2011).

71. Richard D. Kahlenberg, All Together Now: The Case for Economic INTEGRATION OF THE PUBLIC SCHOOLS 83 (2001); USHOMIRSKY \& WILLIAMS, supra note 26, at 4 ("In 17 states, high-poverty districts receive substantially (at least 5 percent) more in state and local funds than low-poverty districts.").

72. USHOMIRSKY \& WILLIAMS, supra note 26 , at 4.

73. Baker \& Green, supra note 53, at 234.

74. See Tang, supra note 70, at 1204-06 (observing that it is difficult to measure how much funding each student needs, difficult for the state to replace substantial local funding with its own revenues, difficult to pass legislation that redistributes property tax revenues, and difficult to translate a judicial description of a constitutional funding scheme into legislation that achieves the desired outcome).

75. New Jersey's struggle has been described as "truly breathtaking," in that the 2009 "opinion of the New Jersey Supreme Court in Abbott v. Burke was that court's twentieth opinion over as many years," and was preceded by a previous line of cases stemming out of Robinson $v$. Cahill, which "also yielded several opinions over the course of twenty years." Bauries, supra note 63, at 334 .

76. Leandro v. State, 488 S.E. 249, 257 (N.C. 1997). North Carolina rejected an equity conception of the state's constitutional guarantee, finding instead a guarantee to a minimally adequate level of education. $I d$. 
So, perhaps partially for practical reasons, state courts have not been entirely receptive to arguments about equity and have not often struck down educational funding systems on those grounds. Although different studies measure different time periods and use different conventions to qualify a lawsuit as an equity suit, it appears that the second wave was successful somewhere between 32 percent and 45 percent of the time. ${ }^{77}$ Perhaps such success rates are common for legal efforts attempting to make social change ${ }^{78}$ but education finance reform litigants began to explore new strategies.

Changing tactics in the late 1980s, litigants began to argue that insufficiently funded public education systems deprived children of a minimally adequate level of education such that it violated state constitutional education clauses. $^{79}$ The third wave of state constitutional adequacy reform litigation abandoned equity comparisons between the educational resources and outcomes of different students in favor of the premise that state constitutions guaranteed all children a minimally adequate level of public education. A typical definition of adequacy might include language like "a specific level of resources required to achieve certain educational outcomes." 80 The case best known for articulating adequacy reasoning is Rose $v$. Council for Better Education. ${ }^{81}$ In Rose, the Kentucky Supreme Court held that education is a fundamental right in Kentucky, and that the legislature is constitutionally required to provide a "substantially uniform" public school system dedicated to instilling certain "capacities" in its students. ${ }^{82}$ Following Rose's lead, the North Carolina Supreme Court likewise held that the North Carolina constitution

77. Michael A. Rebell, Educational Adequacy, Democracy, and the Courts, in ACHIEVING High EduCATIONAL STANDARDS FOR All 227 \& n.53 (Timothy Ready, Christopher Edley, Jr. \& Catherine E. Snow eds., 2002) [hereinafter Rebell, Educational Adequacy]; Tang, supra note 70 , at $1202 \&$ n.24. It is difficult to find consistent data about the number of times state funding systems were judicially invalidated as compared with the total number of lawsuits challenging them. Reasons for this disparity include differences in methodology for defining what an adequacy versus an equity suit was, as well as the years covered by the study.

78. See generally Richard Kluger, Simple Justice: THE History OF BROWN V. BOARD OF EDUCATION AND BLACK AMERICA's STRUGGLE FOR EQUALITY (2011) (explaining a long series of litigation efforts before the eventual victory).

79. See Thro, supra note 66 , at 603 .

80. Koski \& Hahnel, supra note 65 , at 47.

81. Rose v. Council for Better Educ., Inc., 790 S.W.2d 186 (Ky. 1989).

82. More specifically, the public school system in Kentucky was to provide its students with skills to "function in a complex and rapidly changing civilization" and to "compete favorably with their counterparts in surrounding states, in academics or in the job market." Id. at 201, 212. 
guaranteed "a sound basic education" that amounted to "sufficient academic and vocational skills." 83

If a court finds the state's public school funding system to be constitutionally inadequate, the typical remedy requires the legislature first to measure the cost of providing an adequate education for each student and, second, to guarantee that the state will cover the shortfall for districts unable to reach that amount for its students. ${ }^{84}$ This approach faces challenges similar to the definitional and administrative difficulties encountered by the state constitutional equity litigation approach. Yet, state courts have evidently been more receptive to adequacy arguments than equity arguments. Between 54 percent and 66 percent of adequacy-based litigation reform efforts were successful in persuading state courts that the funding system in question violated the relevant state constitution. ${ }^{85}$

While much scholarly hay has been made asserting the superiority of either the equity or adequacy approach, ${ }^{86}$ practically speaking, it is not entirely clear whether the distinction matters. ${ }^{87}$ Education reform litigation history is significant because, regardless of the approach, litigants draw upon the same set of core competing values that continue to guide purposeful discourse about education finance.

83. The court further explained that such skills ought "to enable the student to compete on an equal basis" in the future, whether that took place in higher education or employment. Leandro v. State, 488 S.E.2d 249, 257 (N.C. 1997).

84. Koski \& Hahnel, supra note 65 , at 46.

85. Michael A. Rebell, Educational Adequacy, supra note 77, at 227; Tang, supra note 70, at 1202 \& n.24. Layering recession-era economics atop the success of adequacy litigation, Rebell later observed that "[a]lthough before 2008, plaintiffs had won two-thirds (twenty-three of thirtythree) of state court adequacy decisions, their success rate has been halved in the most recent cases: they have prevailed in only three of the nine adequacy cases decided since 2008." Rebell, Safeguarding, supra note 30, at 1889.

86. See, e.g., William S. Koski \& Rob Reich, When "Adequate” Isn't: The Retreat from Equity in Educational Law and Policy and Why It Matters, 56 EMORY L.J. 545, 547 (2006) ("[T[he recent shift away from equity-minded policies to adequacy-minded (or equity-neutral) policies must be reconsidered ....”); Regina R. Umpstead, Determining Adequacy: How Courts are Redefining State Responsibility for Educational Finance, Goals, and Accountability, 2007 BYU EDUC. \& L.J. 281, 284 (2007) (explaining "that although the adequacy lawsuits can be broadly conceived as encompassing the three components of educational funding, goals, and accountability, it is the requirement that a state government provide sufficient funding for a basic quality education that dominates the court decisions"); see also John Dayton \& Anne Dupre, School Funding Litigation: Who's Winning the War?, 57 VAND. L. REV. 2351, 2411 (2004) (concluding that between equity and adequacy, "[i]t is doubtful whether either side will be able to claim victory any time soon").

87. Litigants often articulate their arguments borrowing from both equity and adequacy theories and, just as often, judicial decisions reflect the choice to borrow from both equity and adequacy rationales. See Weishart, supra note 57, at 478-79 (noting that "a number of courts have incorporated or invoked equality and adequacy in tandem"). 
Taking the second and third waves together, education reform litigation has resulted in nearly every state facing some type of state constitutional challenge to its public education funding system. ${ }^{88}$ In turn, litigation appears to consistently spur educational funding reform in some capacity. ${ }^{89}$ Even beyond reform litigation, some state legislatures have attempted to improve the fairness of educational funding formulas absent the prompting of a court order. ${ }^{90}$ Ultimately, virtually every state has obligated itself to avoid a public education formula whereby the quality of a school is directly related to the property wealth of the community. States have largely attempted to discharge that obligation by shifting financial responsibility for education away from local property taxes and toward state and federal funding sources, recalibrating an already complicated funding scheme for public education. ${ }^{91}$

\section{B. The Consequences of Education Funding Reform Litigation}

As it was before reform litigation, state aid is calculated using formulas. The variation of these formulas cannot be understated. ${ }^{92}$ In response to reform litigation, most states initiated changes to their funding formulas in some capacity; typically, states limited the amount of local funding for schools and replaced it with ostensibly more equitable state funding. ${ }^{93}$ Because states have attempted to accomplish this in different ways, their various methodologies resist organized categories ${ }^{94}$ in part because many states use a combination of several

88. Michael Podgursky, James Smith \& Matthew G. Springer, A New Defendant at the Table: An Overview of Missouri School Finance and Recent Litigation, 83 PEABODY J. EdUC. 174, 176 (2008) ("Only 5 states-Delaware, Hawaii, Mississippi, Nevada, and Utah-have not had their state school funding mechanisms adjudicated in the courts.").

89. Berry, supra note 27 , at 214 (finding small or no statistically significant impact on school finance as a result of equity or adequacy litigation, but noting that litigation reliably leads to increasing centralization of funding; that is, more state and federal funding relative to local funding).

90. Corcoran \& Evans, supra note 25, at 353.

91. Berry, supra note 27 , at 214.

92. See generally Lawrence O. Picus, Margaret E. Goertz \& Allan R. Odden, Intergovernmental Aid Formulas and Case Studies, in HANDBOOK OF RESEARCH IN EDUCATION FINANCE AND POLICY, supra note 12, at 279 (reviewing various formulas); Deborah A. Verstegen \& Teresa S. Jordan, A Fifty-State Survey of School Finance Policies And Programs: An Overview, 34 J. EDUC. FIN. 213 (2009) (providing an overview of different states funding formulas).

93. Richard Rossmiller, Funding in the New Millennium, in EDUCATION FINANCE IN THE NeW MillenNium 11, 24 (Stephen Chaikind \& William J. Fowler eds., 2001).

94. Categorization is also challenging because different studies often describe the same methodology but give it different names or categorize a single state's approach in two different 
methodologies.$^{95}$ Most states, however, use some form of a "foundation program," whereby the state guarantees a "foundation amount" per student or teacher "unit" and compensates up to that amount if local funding, based on a uniform tax rate, falls short. ${ }^{96}$ Whatever the formula, funding is typically adjusted in some way for students who are disabled, have special education needs, are learning English, or come from lower-income households. ${ }^{97}$

Although the amount of state aid is based in part on the amount of local property tax revenue ${ }^{98}$ following education reform litigation, the amount of local property tax revenue available to a school district is frequently subject to various state-level limitations. ${ }^{99}$ These limitations attempt to put distance between school funding and local property values by replacing local with state funding. Public finance reform litigation, therefore, reliably led to increased centralization of public education, or in other words, relatively more significant decisionmaking and funding roles for the state and the federal government. This trend toward centralization gained further momentum after the National Commission on Excellence in Education published its 1983 report titled $A$ Nation at Risk. ${ }^{100}$ This report

ways. For example, one source designates Vermont's formula as a district power equalizing system. Verstegen \& Jordan, supra note 92, at 213. Another says it is two-tiered. U.S. DEPT. OF Educ., NAT'L CTR. For Educ. Statistics, Public School Finance Programs of the UNITED STATES AND CANADA: 1998-99: VERMONT (2001), https://nces.ed.gov/edfin/pdf/ StFinance/Vermont.pdf [https://perma.cc/8SV5-4B4Y]. Some of this confusion is likely due to state legislatures changing their formulas with relative frequency, making it exceedingly difficult to provide an overview of all fifty states at any given moment in time.

95. Verstegen \& Jordan, supra note 92, at 213.

96. Id. at 215. Rather than using a foundation program, three other states use a "district power equalization system," which allows school districts to tax and spend with limited discretion, "and the state matches differences in what is raised locally and what is guaranteed." Id. at 216. Hawaii, which has one school district uses a "full funding" formula, and North Carolina uses a "flat grant" formula. Verstegen \& Jordan, supra note 92, at 213.

97. Id. at 218, 221. Like the federal government, states often also have separate grants dedicated to these groups of students. $I d$. at 213.

98. Id. (noting that some states compensate for local property tax disparities, "leave them untouched, or make them worse"). For an additional layer of complexity, federal aid is based in part using the "average level of school spending in the state." Gordon, supra note 12, at 325.

99. YUDOF ET AL., supra note 10, at 808 ("Local funding is a product of the tax rate and the property wealth in a district. Because some districts have more property wealth than others, they are able to raise more money at any given tax rate.").

100. BENJAMIN MichaEl SuPERfine, THE COURTS AND STANDARDS-BASEd EduCATION REFORM 25-26 (2008); Gordon, supra note 12, at 328; see, e.g., Betheny Gross \& Paul T. Hill, The State Role in K-12 Education: From Issuing Mandates to Experimentation, 10 HARV. L. \& POL'Y REV. 299, 307-08 (2016) (describing several pieces of legislation enacted after $A$ Nation at Risk was published where federal or state authorities were setting education goals for public schools). 
"highlighted the lagging results of United States students," and resulted in cries for increased state and federal accountability. ${ }^{101}$

With increasingly centralized funding, schools found themselves more vulnerable to statewide budget cuts because districts were unable to replace lost state revenues with local property tax revenues, which were now subject to limitation. ${ }^{102}$ In some cases, most notably in California, equalization efforts resulted in a leveling down of funding, and the quality of all public schools in the state suffered. ${ }^{103}$ For all states, even those that did not experience leveling down, economic recessions resulted in statewide budget cuts. ${ }^{104}$ These shortages were made worse by schools' increasing responsibility to provide services that were historically performed by social services agencies, such as providing meals, coordinating with the healthcare and foster systems, ${ }^{105}$ and instructing and caring for special needs students. ${ }^{106}$ So, schools began to examine fundraising options beyond traditional PTA bake sales and car washes.

One solution was to form an LEF, a nonprofit charitable organization that raises money and provides grants to schools for teacher development and other programs. ${ }^{107}$ Most LEFs are organized at the district level, and while some are organized at the individual school level, those groups still often report to a districtwide umbrella LEF. ${ }^{108}$ LEFs joined the ranks of other school-supporting nonprofits

101. Gross \& Hill, supra, note 100, at 307; see also Gordon, supra note 12, at 328-29 (discussing the report and its effects).

102. Nelson \& Gazley, supra note 32 at 546.

103. For a discussion of the effects of leveling down, see supra note 28 and accompanying text.

104. See generally MichaEl LEACHMAN \& CHRIS MAI, CENTER ON BUdGet AND PoliCY Priorities, Most StATES Funding SCHOOls Less THAN BEFORE THE RECESSION (2014), http://www.cbpp.org/sites/default/files/atoms/files/9-12-13sfp.pdf [https://perma.cc/A5LXA2FA].

105. USHOMIRSKY \& WILLIAMS, supra note 26, at 4.

106. Mokoto Rich, Nation's Wealthy Places Pour Private Money into Public Schools, Study Finds, N.Y. TIMES (Oct. 21, 2014), http://nyti.ms/1FzDUsQ [https://perma.cc/2SLV-C3A2].

107. See Janet S. Hansen, Michelle Hall, Dominic J. Brewer \& Jane Hannaway, The Role of Nongovernmental Organizations in Financing Public Schools, in HANDBOOK OF RESEARCH IN EDUCATION FINANCE AND POLICY, supra note 12, at 336, 340 (observing that schools have increasingly turned to LEFs to raise supplementary funds); Nelson \& Gazley, supra note 32, at 541.

108. See Phyllis de Luna, Local Education Foundations: Right for Many Schools, 79 PHI DELTA KAPPAN 385, 387-88 (1998) ("Some LEFs are more independent of the school district than others."). As one report noted:

As opposed to PTAs, PTOs, and booster clubs, LEFs typically operate at the district level, but they are independent of the school districts they serve. A common model for a LEF consists of a single foundation that serves all the schools in one district. On the 
and did fundraising work on top of the fundraising that PTAs, alumni associations, and booster clubs at individual schools had been doing for decades. ${ }^{109}$ Together, these ESOs began to mobilize in much more sophisticated and significant ways in the 1980s - for example, through "phonathons," "direct solicitation letters, dinners, golf tournaments, and auctions" - as they attempted to more effectively solicit donations to offset decreases in public funding. ${ }^{110}$ As public sources of funding become more centralized, ESOs continue to grow in popularityperhaps because they provide a way for communities to continue contributing to public education, in lieu of limited "official" local property tax contributions.

\section{States Should AdDRESS PRIVATE DonAtions to PUbliC SCHOOLS}

This Part argues that states should not postpone addressing private donations to public schools, because at a minimum, the normative implications of private donations to public schools are concerning. It is true that studies have not conclusively demonstrated that private donations make a meaningful contribution to the inequity of school funding. It is also true that studies have not conclusively demonstrated that better funding makes a better school. But, as this Part suggests, the societal importance of education merits consideration in advance of firm quantitative evidence of inequality. Although there are similar concerns about the equitable implications of private funding for public goods in general, the nature of education and its role in society make those tensions more troubling in the context of private donations to public schools. For this reason, this Part proposes that state legislatures are the appropriate governing body to address donations because public schools are traditionally the state's

other hand, some LEFs and the districts they serve allow individual schools to form their own foundations. Another model is a single foundation that serves several districts in a region.

ZIMMER ET AL., supra note 15 , at 15.

109. Hansen et al., supra note 107 , at 340 .

110. de Luna, supra note 108, at 386. But see Ashlyn Aiko Nelson, The Effect of Tax and Expenditure Limitations on Voluntary Contributions to Public Schools 29, 38-40 tbl.2, 41-43 tbl.3 (Apr. 24, 2015) (unpublished manuscript), http://ssrn.com/abstract=2597680 [https://perma.cc/ 74Z5-7AXH] (finding a significant correlation between state tax and expenditure limits (TELs) and charitable activity by school-supporting nonprofits, but finding "no causal evidence that TELs either increase the probability that a school-supporting nonprofit locates within a district, or increase the level of voluntary contributions to public schools"). 
responsibility, and donations threaten to undermine the efforts states have been making to equalize school funding.

\section{A. Absent Conclusive Proof of Exacerbating Inequality, Studies Foreshadow Trouble}

It has been difficult for scholars to quantify the fiscal impact of private donations, in part because of the enormity of the budget for public education. Because private donations comprise a small piece of such a large pie, there is no evidence to date that local education nonprofits have led to large disruptions of revenue equality across most schools. ${ }^{111}$ Further, the assertion that "[p]ublic schools spend more each year than the entire gross domestic product of every country in the world, except for the 16 wealthiest nations," supports the argument that "private contributions are just too small to make much of a difference, even if public schools are lacking in money compared to their responsibilities." 112 Thus, measures that discourage private donations because they amplify funding gaps are based on admittedly imperfect empirics. ${ }^{113}$

But, even studies purporting to quantify the financial impact of private donations use different methodology and data, which may explain why some studies reach contradictory conclusions. Many studies use data from the early 2000s, and even the most recent national data is from 2010. ${ }^{114}$ Age alone reduces the salience of those studies,

111. See Jay P. Greene, Buckets into the Sea, in With THE BEST OF InTENTIONS 49, 57 (Frederick M. Hess ed., 2005) (arguing that the dollar values of $\$ 1.5$ billion in private donations sound significant, but pale in comparison to the $\$ 400$ billion public budget); Nelson \& Gazley, supra note 32, at 545-46 (noting the "significant body of research suggest[ing] that voluntary contributions to public education do not constitute a viable alternative to tax revenues and are not sufficiently sizable to overcome government failure").

112. Greene, supra note 111, at 57. Greene also argues by analogy that although "most people do not think of Russia as a rich country," despite Russia producing " $\$ 433$ billion in goods and services every year, about the same as what public schools spend," most people would also "agree that offering [Russia] a mere $\$ 1.5$ billion ... would be very unlikely to change Russian policy in any meaningful way. It's just too little relative to all of the resources Russia already has at its disposal, even if Russia also has enormous needs to satisfy." Id. at 58.

113. Nelson \& Gazley, supra note 32, at 545-46 (highlighting the growing role of private donations following the Great Recession, as demonstrated by studies in California and Florida).

114. Greene uses data from 2001. See Greene, supra note 111, at 49. Nelson and Gazley use data from 2010. Nelson \& Gazley, supra note 32, at 541. One more recent study uses data from 2013-2014 to estimate that parent teacher groups supporting a local school raised $\$ 425$ million in that fiscal year, and examined the inequitable distribution of private donations on a local level within several school districts. CATHERINE BROWN, SCOTT SARGRAD \& MEG BENNER, CTR. FOR Am. Progress, Hidden Money: The Outsized Role of Parent Contributions in 
but the statewide budget cuts that followed the 2008 economic recession add reason to question them, as dependence on private resources appears to have increased simultaneously. ${ }^{115}$ If ESOs continue to grow at their current pace, it is possible that the resulting growth in private donations could outpace public funding growth and someday reach the point of quantitative significance. ${ }^{116}$

Even without data of private funding contributing to funding inequality, evidence shows a distribution of ESOs along socioeconomic lines that is troubling, regardless of their quantitative significance. Studies show that ESOs are more likely to be organized in larger districts that boast relatively more educated and wealthy residents, and less unemployment, poverty, and single parenting. ${ }^{117}$ Some national ESOs have acknowledged that "in the beginning, we were organizing white middle class parents," and that strategies are necessary to break that mold and account for diverse racial and economic realities. ${ }^{118}$ While corporations and local businesses donate to underfunded districts, there is a risk that companies shy away from chronically underfunded rural areas, ${ }^{119}$ where they have less brand recognition, and from urban neighborhoods that suffer from unreliable community and educational infrastructures, where it is less certain that their money is spent efficiently. ${ }^{120}$ Although schools in areas with less property wealth

SCHOOL FINANCE 5-7 (2017), https://www.americanprogress.org/issues/education/reports/2017/ 04/08/428484/hidden-money [https://perma.cc/SE27-49N5].

115. Nelson \& Gazley, supra note 32, at 552.

116. Michael F. Addonizio, Private Funding OF Public Schools: LocAl EduCATION FOUNDATIONS IN MICHIGAN 15 (1998) (warning that when public funds are insufficient and budget cuts continue, this could encourage private donations and make a difference in equity).

117. Nelson \& Gazley, supra note 32, at 559; see also BROWN, SARGRAD \& BENNER, supra note 114, at 5 (asserting that "the nation's wealthiest PTAs are found in high-income school districts or in high-income schools within lower-income districts").

118. Jacqueline Raphael \& Alissa Anderson, Leading Ways: Preliminary Research on LEF Leadership for the Public Education Network, Urb. Inst. 12 (2002), https://www.urban.org/ sites/default/files/publication/60596/410580-Leading-Ways-Preliminary-Research-on-LEF-

Leadership-for-the-Public-Education-Network [https://perma.cc/5W2W-Z6V7].

119. See Anna Williams Shavers, Rethinking the Equity vs. Adequacy Debate: Implications for Rural School Finance Reform Litigation, 82 NEB. L. REV. 133, 142 (2003) ("The industrial revolution, shifts in population, and the location of businesses and other taxable property led to disparities in taxable property, resulting local revenue, and levels of expenditure available for education. Small rural schools began to suffer from lack of resources.”); see also John Schomberg, Equity v. Autonomy: The Problems of Private Donations to Public Schools, 1998 AnN. SURV. AM. L. 143, 160 (1998).

120. Lucas R. Salzman, Public Goods, Private Money: The Role of Private Contributions In Public School Districts 45 (Mar. 31, 2014) (unpublished B.A. thesis, University of Pennsylvania), $\mathrm{http}: / /$ repository.upenn.edu/cgi/viewcontent.cgi? article $=1207 \&$ context $=$ curej

[https://perma.cc/5J8M-EVXJ]. 
do receive support from ESOs, they have to work harder to achieve similar funding through local businesses and corporations or reach beyond the local community. ${ }^{121}$ This information may not show up on a report examining overall financial inequality, but in combination with the evidence of exponential growth in ESOs ${ }^{122}$ it raises the troubling possibility of ESOs someday compounding the inequalities related to local revenue disparities and creating the sort of two-tiered public education system that most states have struggled to avoid for the last fifty years. ${ }^{123}$

Next, studies that examine whether more money results in better schools do not have consistent results. ${ }^{124}$ Some studies have concluded that more money improves educational outcomes, though others conclude that, even if money does make a difference, it is not significant enough to determine educational outcomes. This debate, therefore, is a good candidate for a balanced legislative solution. If money matters, then freely permitting private donations to public schools creates an unfair advantage for students in schools receiving more donations, and completely prohibiting private donations reduces the total amount of money available to public schools and risks leading to a leveling down of the quality of education for all students in the state. If money does not matter, then private donations provide no advantage to their recipients and serve only to create the troubling appearance of inequity. On balance, then, these arguments give way to

121. ZIMMER ET AL., supra note 15, at 57; see also Salzman, supra note 120, at 45 (suggesting that school districts with high concentrations of poverty yield lower donation revenues, perhaps due to operational difficulties dissuading donors from donating).

122. Id.

123. USHOMIRSKY \& WILLIAMS, supra note 26 , at 4.

124. The Coleman report in 1966 upset long-held assumptions that more money resulted in better academic performance. Gross \& Hill, supra note 100 at 307; see also SUPERFINE, supra note 100, at 127 ("[T]he causal links between expenditures and educational opportunities are often opaque."). But several scholars argue that money does make a difference, especially as it relates to teacher quality. See KAHLENBERG, supra note 71, at 83 (arguing that the disappointing results of increased Title I funding increases does not make money irrelevant); Michael F. Addonizio, $X$ Efficiency and Effective Schools: A New Look at Old Theories, 35 J. EDUC. FIN. 1, 2 (2009) (discussing research linking increased funding and teacher quality to student achievement); Kevin Carey \& Elizabeth A. Harris, It Turns out Spending More Probably Does Improve Education, N.Y. TIMES (Dec. 12, 2016), http://nyti.ms/2hfv3YM [https://perma.cc/X8D5-PRV3] (noting poor school districts that received additional money saw more academic improvement than peer districts); Is There a Better Way to Pay for America's Schools?, NPR (May 1, 2016 7:00 AM), http://www.npr.org/2016/05/01/476224759/is-there-a-better-way-to-pay-for-americas-schools [https://perma.cc/XZ2M-KX5W] ("[M]oney, spent wisely and consistently, can improve the lives and outcomes of disadvantaged students."). 
each other and provide additional reason for states to address private donations to public schools.

One last reason to address the inequitable implications of private donations even before solid quantitative grounding is the fact that schools themselves seem to take fundraising and its effects seriously. Some schools and districts even hire outside consultants to help them raise money through foundations. ${ }^{125}$ At least one district's failure to establish foundations has resulted in financial difficulty and inequality, ${ }^{126}$ and by and large, LEFs seem to be a solution to budget cuts that are on the table for most schools. Further, some ESOs have acknowledged a responsibility to address equity concerns ${ }^{127}$ which is persuasive evidence that those concerns have merit.

\section{B. Private Donations to Public Schools Require More Complex Analysis Than Private Donations to Other Public Goods}

The debate about private donations to public schools fits into a larger debate about private funds for the provision of public goods, generally. ${ }^{128}$ Many argue that the line between public and private goods has always been a blurry one. For example, Andrew Carnegie famously founded the public library system with private money, and hospitals that historically relied on public funding have increasingly turned to private funding since the $1980 \mathrm{~s}^{129}$ Neither of these sorts of donations

125. Arthur H. Roach, Fundraising Basics for Private School Facilities, Nat'l Clearinghouse for Educ. Facilities 1 (2009), http://www.ncef.org/pubs/fundraising.pdf [https://perma.cc/892C2PJ7] (suggesting public schools fundraising for capital improvements should hire a consultant to assist).

126. San Diego's failure to establish an LEF resulted in a fragmented collection of schoollevel LEFs. Lynn Jenkins \& Donald R. McAdams, Philanthropy and Urban School District Reform: Lessons from Charlotte, Houston, and San Diego, in WITH THE BEST OF INTENTIONS, supra note 111 , at $129,153$.

127. Raphael \& Anderson, supra note 118, at 3 (noting one former LEF director's recollection that "[w]hen I look back on our early organizing efforts, [I realize] we were organizing middleclass white parents. Now ... we recognize the need to reach the lower class in order to break the cycle of dropouts").

128. See, e.g., Margaret H. Lemos, Privatizing Public Litigation, 104 GEO. L.J. 515, 517-19 (2016) (observing that privatization's "advocates argue that outsourcing work to private firms is more efficient than relying on bloated government bureaucracies," while "[c]ritics ... contend that any efficiency gains come at an intolerable cost to democratic and programmatic accountability" (footnotes omitted)).

129. Jane Haderlein, Unleashing the Untapped Potential of Hospital Philanthropy, 25 HEALTH AFF. 541, 542 (2006) ("A minor funding source for nonprofit community hospitals in recent decades, philanthropy is now gaining traction as a viable and available alternative source of much-needed capital.”); Cagla Okten \& Burton A. Weisbrod, Determinants of Donations in Private Nonprofit Markets, 75 J. PUB. ECON. 255, 261 n.6 (2000) ("In the hospital industry, the 
appear to inspire outrage; in fact, they are often seen as innovative. An ESO director predicted a similarly optimistic future for public school fundraising, noting that "[y]ears ago, no one would have considered private fund raising for hospitals, and look where that's at now."130 Private support for public education is not new either. Private donations to public universities are common, and in the South during Reconstruction, private philanthropist Julius Rosenwald paved the way for educational gains for African Americans by building primary schools and negotiating with state governments to eventually take them over. ${ }^{131}$ In spite of this history, however, there is reason to be more careful about private donations to public schools than to other public goods. The "market" interaction between a state's constituents and its schools is quite different than the interaction between constituents and hospitals. It is likely easier for a constituent to choose a different library, hospital, or public university to better suit one's needs than to choose a different public primary or secondary school. For example, unlike schools, individuals are not generally predesignated to seek services at a specific hospital based on their addresses, and it is generally unnecessary to fill out a transfer request or get approval to receive services at the individual's hospital of choice. ${ }^{132}$ So, it is more imperative that the state play an active role in managing the quality of public education services.

fundraising percentage fluctuated in the narrow range of 0.1 to $0.2 \%$ throughout the $1982-1988$ period, but increased to $0.3 \%$ in 1989 and remained essentially stable thereafter."); Susan Stamberg, How Andrew Carnegie Turned His Fortune into a Library Legacy, NPR (Aug. 1, 2013 3:00 AM), http://www.npr.org/2013/08/01/207272849/how-andrew-carnegie-turned-his-fortuneinto-a-library-legacy [https://perma.cc/PA3T-9XFB].

130. Sarah Carr, Private Funds Padding Public School Coffers: Gifts Cover Shortfalls But Raise Concerns of Education Inequalities, MilwauKeE J. Sentinel, Nov. 17, 2004, at A01.

131. David Strong, Pamela Barnhouse Walters, Brian Driscoll \& Scott Rosenberg, Leveraging the State: Private Money and the Development of Public Education for Blacks, 65 AM. SOC. REV. 658, 673 (2000) (explaining that Rosenwald built schools with privately raised funds, on the condition that the state treat such schools like all other state-established public schools, or in other words, "continuing to sustain and operate it"); see also Peter Frumkin, Strategic Giving and Public School Reform, in WITH THE BEST OF INTENTIONS, supra note 111, at 275, 275 (explaining that Rockefeller, through higher education, and Carnegie, through public libraries, "embraced the more difficult goal of remedying the underlying forces that made social welfare agencies necessary" rather than participating in traditional almsgiving).

132. See, e.g., Transfer Requests, MOlOlla RIVER SCH. DisT. (Jan. 31, 2017), http://www.molallariv.k12.or.us/parents/transfer_requests [https://perma.cc/5UMA-ZUHP] (providing paperwork for inter-district transfer applications); Student Transfer Requests, N. THURSTON PUB. SCHS. (Jan. 31, 2017), https://www.nthurston.k12.wa.us/transfers [https:// perma.cc/W8G2-GPGB] (explaining procedure for transfer requests). A person's choice of medical providers can be restricted by insurance coverage, or lack thereof, which may well 
Further, acquiescing to private donations for schools, based simply on the historical precedent of private donations for hospitals, relies on an imperfect analogy. Private donations to public hospitals became more popular in the 1980s, after "a number of public hospitals had wellpublicized financial crises" due in part to higher medical costs and cuts to public funding. ${ }^{133}$ In this respect, the history of hospitals sounds quite similar to the history of public education, but the analogy is of limited help in making normative assessments. The mixture of public and private funding for hospitals seems to have fluctuated over time in response to an unpredictable funding environment because, unlike public schools, hospitals lack comprehensive statutory provision. ${ }^{134}$ Unlike public schools, hospitals are not power players in a state's budget. Because such a huge proportion of the budget is spent on education, legislation about funding for public education shapes the state's economic environment in a way hospital funding never could. ${ }^{135}$ Thus, regardless of whether a laissez-faire approach is appropriate regarding private donations to public hospitals, that approach is not appropriate regarding public education.

Next, because of the societal role of education, a voluntary contribution to a school feels different than a voluntary contribution to another public good, like an art museum. The donor likely benefits in some way from both public donations; for that matter, it is debatable whether any charitable donation is devoid of selfish motivations. ${ }^{136}$ But perhaps a donation to the school one's children attend is less altruistic than a comparable donation to an art museum. Donating to the school returns a tangible benefit back to the donor's children along with a defined school community to which its members are assigned. A donation to an art museum benefits the donor no more than it benefits

correlate with socioeconomic status. Such restrictions are beyond the scope of this discussion, which focuses on direct governmental regulation of access to public goods.

133. Email Correspondence with Emily M. Kern, Ph.D. candidate, History of Science, Princeton University (Dec. 20, 2016) (on file with author) (citing CHARLES RosENBERG, THE CARE OF STRANGERS: THE RISE OF AMERICA's HOSPITAL SYSTEM; and then ROSEMARY STEVENS, IN SiCKNESS AND IN WEALTH: AMERICAN HOSPITALS IN THE 20TH CENTURY).

134. Id. Interestingly, Kern notes that in the face of irregular public funding, many state hospitals "seem to be survivors because they're plugged into the state educational systems" through a medical school. Id.

135. Id.; see also YUDOF ET AL., supra note 10, at 806 (explaining that states dedicate 20 percent of their overall budgets to education).

136. See, e.g., James Andreoni, Impure Altruism and Donations to Public Goods: A Theory of Warm-Glow Giving, 100 ECON. J. 464, 468 (1990) (arguing that charitable donors are not purely altruistic and instead prefer to make donations that maximize the "warm glow" they feel from making the donation). 
the community, the members of which self-select, either choosing to take advantage of the benefit by visiting the museum or not. On the other hand, perhaps a donation to the local public school is more altruistic than spending that money hiring a private tutor, because other children at the school will benefit from the additional donated resources, and the community as a whole derives benefits from better education. Because the policy implications of private donations to public schools are closer and more nuanced than private donations to other public goods, these arguments are unlikely to resolve themselves. State legislatures, therefore, must sift through the arguments and make an executive policy decision about the appropriate role of private donations to public schools.

\section{State Legislation Is the Appropriate Way to Address Private Donations to Public Schools}

Several school districts have independently enacted policies that attempt to offset the inequitable implications of private donations by requiring a portion of donated funds to be directed toward the other schools in the district. A federal entity managing this aspect of public education finance could offer advantages over state-level management ${ }^{137}$ as interstate disparities in overall public education funding are certainly alarming ${ }^{138}$ and after all, any ESO that qualifies as 501(c)(3) charitable organizations receives substantial tax subsidies from the federal government. ${ }^{139}$ But, the federal government has demonstrated little interest in addressing ESOs beyond the existing

137. See, e.g., Kimberly Jenkins Robinson, Disrupting Education Federalism, 92 WASH. U. L. REV. 959, 1006-12 (2015) (arguing that despite limits placed on congressional authority by National Federation of Independent Businesses v. Sebelius, 132 S. Ct. 2566 (2012), there is room for Congress to expand the federal role in education); see also Michael Heise, The Political Economy of Education Federalism, 56 EMORY L.J. 125, 153-56 (2006) (arguing that the federal government should shoulder both fiscal responsibility and control over dictating national education policy); Erika K. Wilson, Toward a Theory of Equitable Federated Regionalism in Public Education, 61 UCLA L. REV. 1416, 1424 (2014) (arguing that "localist educational governance structures" are detrimental to achieving fiscal or racial equality between neighboring school districts).

138. Rossmiller, supra note 93, at 24.

139. Reich, Repugnant, supra note 41, at 468. Further, individual tax benefits from charitable contributions are significantly more likely to be realized by middle- and upper-class donors, who are more likely to itemize their deductions-individuals who instead take the standard deduction get no tax benefit from charitable contributions. I.R.C. $\$ \$ 63(c), 170$ (2012). 
federal grant programs. ${ }^{140}$ And, because education is a "matter traditionally reserved to the states," 141 the existing legal infrastructure contemplates decisions by the state. This political legitimacy is buttressed by explicit state constitutional provisions regarding education.

Local governments can, and have, ${ }^{142}$ attempted to address the equitable implications of private donations to public schools. Although perhaps individual schools or districts can adopt policies to address these sorts of issues in a more nimble and timely fashion than a state government, individual schools do not feel any intradistrict disparities resulting from private funding sources ${ }^{143}$ and, by the same reasoning, individual districts lack incentive to address interdistrict disparities.

Ultimately, however, state legislatures have shouldered the burden of addressing concerns about the relationship between socioeconomic status and education, by centralizing funding and limiting the amount of local financial support. ${ }^{144}$ As it stands, private donations appear to allow an end run around equalization efforts, and ignoring private donations abdicates the states' burden. Efforts to equalize funding predictably result in more state and federal funding relative to local funding and "overall school funding levels frequently drop when the state assumes greater responsibility for education."145 As a response to the overall drop in funding resulting from equalizing

140. The Department of Education appears to have shown interest in transparency about private donations to public schools by requiring states to report sources of private funding in census data. See supra notes 4-6 and accompanying data.

141. Wilmore v. Annear, 65 P.2d 1433, 1437 (Colo. 1937).

142. See de Luna, supra note 108, at 387 ("The Portland Public Schools Foundation, for example, keeps $33 \%$ of the funds raised by its member foundations to equalize the benefits of its activities in all the schools in the district."); Nelson \& Gazley, supra note 32 at 563 ("California's Santa Monica-Malibu, Manhattan Beach, and Palo Alto school districts recently adopted policies to pool voluntary contributions at the district level for redistribution across all schools."); Lynh Bui, Montgomery Examines Fairness of Private Funding for School Projects, WASH. PosT (Aug. 11, 2013), https://www.washingtonpost.com/local/education/montgomery-examines-fairness-ofprivate-funding-for-school-projects/2013/08/11/50ffee5c-f61b-11e2-aa2e-4088616498b4_story. html?utm_term=.031c89e8a273 [https://perma.cc/DV63-QC3M] (reviewing local efforts to control for inequitable efforts from private donations).

143. Andrew Stark, Drawing the Line: Public And Private in America 66 (2010); see also YUDOF ET AL., supra note 10, at 875-76 (observing district-level policies to offset inequities in donations, and noting that courts and policymakers are less inclined to remedy intradistrict disparities because their causes are less clear).

144. Rossmiller, supra note 93, at 24.

145. Laurie Reynolds, Skybox Schools: Public Education as Private Luxury, 82 WASH. U. L.Q. 755, 812 (2004). 
efforts, there was a predictable increase in ESO activity that corresponded to increases in private donations. ${ }^{146}$

So, with reliance on private funding unlikely to slow, and with lingering questions about the equitable implications of such donations, the issue is ripe for evaluation by states. The results of the survey in Appendix A show that most states have broadly authorized private donations to public schools, and many states have endorsed ESOs specifically. ${ }^{147}$ The results of the survey also show that there is not any state-level regulation about how private donations might implicate fair funding for education. This is inconsistent with efforts that most states have taken to put distance between the quality of public education and the property wealth in any given district. ${ }^{148}$

\section{RELEVANT CONSIDERATIONS FOR REGULATING PRIVATE DONATIONS TO PUBLIC SCHOOLS}

This Part describes competing arguments about private donations to public schools. It is easy to characterize private donations to public schools as yet another instance of wealthy parents jockeying to better position their own children at the expense of others and erecting barriers between themselves and the less fortunate by building a twotiered educational system. It is also easy to characterize a community rolling up its sleeves and fundraising to offset public funding cuts as a classic example of civic engagement. ${ }^{149}$ The stories on the ground do not seem to fit perfectly into either narrative. This Part submits that consideration of the values on both sides of the debate is critical to reaching an appropriate solution.

146. Nelson \& Gazley, supra note 32, at 543.

147. The consistent explicit provision of authority to accept donations may echo general legislative assumptions that wealth redistribution is somewhat more palatable if it directs funds toward lower-income school districts. This principle is also evident in some states' intestacy laws. For example, in Maryland, if an estate passes through intestacy, and there are no qualified heirs "the net estate shall be converted to cash and paid to the board of education in the county in which the letters were granted, and shall be applied for the use of the public schools in the county." MD. CODE ANN., EST. \& TRUSTS § 3-105 (LexisNexis 2011). Professor Doriane Lambelet Coleman generously assisted in the development of these suggestions.

148. For example, at least one state has explicitly acknowledged equity considerations as they relate to local tax contributions. See WASH. REV. CODE ANN. § 28A.500.050 (West 2017) ("[T]he value of permitting local levies must be balanced with the value of equity and fairness to students and to taxpayers, neither of whom should be unduly disadvantaged due to differences in the tax bases used to support local levies.").

149. Telephone Interview with Tristan Duncan, supra note 56. 
First, this Part examines the troubling implications of freely permitting private donations in light of states' efforts to equalize funding for public education. Next, this Part examines the equally troubling implications of a flat ban on private donations in light of the positive externalities they generate and suggests that the appropriate solution is not so simple as a choice between a flat ban or a free-for-all.

\section{A. The Trouble with Permitting Private Donations}

Beyond the concerns discussed in Part II, which lead to the preliminary conclusion that states should address private donations to public schools, other troubling consequences await public school systems that allow unfettered private donations. First, if private donations could someday create a two-tiered system of public schools, it would contravene their nature as a public good. Second, private donations offer an end run around the political process, undermining the democratic legitimacy of school funding, failing to provide schools with predictable and accountable funding, and creating perverse incentives for states to underfund schools.

1. The Drawbacks of a Two-Tiered Public School System. In 1997, Chancellor Rudy Crew was concerned that allowing P.S. 41 parents to pay for a teacher's salary would encourage a two-tiered system of public schools. ${ }^{150}$ One hundred years before Crew turned the parents at P.S. 41 away, philosopher and education reformer John Dewey reasoned that "[w]hat the best and wisest parent wants for his child, that must we want for all the children of the community. Anything less is unlovely, and left unchecked, destroys our democracy." 151 Crew's reasoning for his New York school appears prescient. Fifteen years after the parents of P.S. 41 were turned down, inequality due to private donations seems to have come to pass, at least for some districts. California's efforts to equalize may have been thwarted by fundraising: one district, which raises $\$ 2300$ in donations per student annually, is able to afford "art and music teachers, and Smart technology in every classroom," and another district less than twenty miles away, that fundraises only $\$ 100$ per student annually, can barely afford the basics. ${ }^{152}$

150. Hartocollis, supra note 19, at A1.

151. JOHN DEWEY, THE SCHOOL AND SOCIETY 19 (1907).

152. Reich, Not Very Giving, supra note 36, at A25. 
Crew and Dewey might reasonably be troubled by the juxtaposition of such differently situated school districts. When the government provides a service to any one of its constituents, those services are presumed to be offered at the same level to all of its constituents - "the delivery of a higher level of service to the wealthy side of town rather than to the poor side of town is considered an inequity to be remedied." ${ }^{153}$ Thus, if permitting private donations to public schools risks the provision of different calibers of a public good, then those donations work against core societal values.

Further, these disparities do not exist because individual parents lack motivation to support local schools. Lower income parents face the prospect of "pull[ing] all of the weight by themselves," in schools that do not already have established channels for community support ${ }^{154}$ compounding the difficulty with current distributions of ESOs along socioeconomic lines. A lower-income parent with a less flexible work schedule, and relatively less time and money to spare, can more easily contribute to an ESO that already exists, and may not have the know-how or resources to get one started. As an example, before ultimately suing the state, one group of Kansas parents held a brainstorming session in the school gym to determine the best community response to budget cuts. During the meeting, one parent stood up to explain that even though she had only \$25 left each week after paying her bills, she would rather put it toward her children's education than anything else, even groceries, because education was her children's path to a successful future-a path that had been unavailable to her. ${ }^{155}$ It could be easier to accept a two-tiered system if the private donations giving rise to it perfectly corresponded to a community's desire to support for education, but that does not appear to be the case.

2. The Drawbacks of Avoiding the Political Process. Leaving the door wide open for fundraising outside the public sphere reduces the incentives for middle- and upper-class parents to put pressure on the

153. Clayton P. Gillette, Opting Out of Public Provision, 73 DenV. U. L. ReV. 1185, 1197 (1996).

154. KAHLENBERG, supra note 71 , at 80-81.

155. Telephone Interview with Tristan Duncan, supra note 56. This particular example relates to increasing property taxes, which lends credence first to the idea that it is not only wealthy parents interested in contributing money to avoid the repercussions of budget cuts, and second to the idea that an existing system to channel community support can provide greater opportunities for parents of all socioeconomic backgrounds to contribute. 
state to fund education fully through the political process. ${ }^{156}$ Discouraging private donations, or at least not actively encouraging them as the Tenth Circuit did in Petrella v. Brownback, ${ }^{157}$ is therefore the more democratically legitimate option and results in transparent policy choices. If middle- and upper-class parents have an option other than making their way through bureaucratic red tape, it is entirely rational for them to pick the less difficult and potentially more effective option of private donations. Utilizing the political process, however, raises the bar for students across the state, whether or not their parents are on the front lines pushing for legislative action. In this sense, permitting unlimited private donations is a "laundering" of the same inequitable funds that otherwise would have been raised by property taxes.

Additionally, private fundraising is vulnerable to even more unpredictability than public income streams, due to the voluntary nature of donations. Relying on private donations makes it difficult for schools to plan long-term projects, even though the fundraising methodologies of a sophisticated ESO may be relatively predictable in practice. It is likely preferable to redirect those financial commitments into a funding vehicle that features more certainty than almost anything else-taxes. ${ }^{158}$ Further, the reporting requirements for ESOs range from vague, to limited, to nonexistent - so not only are donations unpredictable in the first place, but it is difficult to account for them after the fact. Again, some information is available through federal

156. See KAHLENBERG, supra note 71 , at 84 (observing that a benefit to socioeconomic integration in schools is that "middle-class parents will use their political weight to bring greater equality of resources").

157. Petrella v. Brownback, 787 F.3d 1242, 1258 (10th Cir. 2015). In Petrella, parents attempted to raise local property taxes to offset budget cuts in Shawnee Mission school district, estimated to cost about $\$ 25$ per household, but were blocked because Kansas law capped how much revenue schools could derive from local property taxes in an effort to equalize funding. Duke Univ. Sch. of Law, supra note 56. The parents sued, alleging violations of their Fourteenth Amendment liberty interest in directing their children's upbringing and education. $I d$. The Tenth Circuit was not persuaded, finding that the Kansas law passed the rational basis test because it "promot[ed] equity in education funding," a legitimate government interest. Petrella, 787 F.3d at 1258. The Tenth Circuit concluded that the parents did not have meritorious constitutional claims, in part because the parents could "donate as much money as they wish[ed]" to their school district, by sidestepping the taxation system. Id.

158. See, e.g., Seattle Sch. Dist. No. 1 v. State, 585 P.2d 71, 97 (Wash. 1978) ("[C]ompliance with Const. art. $9, \S \S 1$ and 2 can be achieved only if sufficient funds are derived, through dependable and regular tax sources, to permit school districts to provide 'basic education' through a basic program of education in a 'general and uniform system of public schools."'); 1 MEMOIRS OF BENJAMIN FRANKLIN 619 (1840) ("[B]ut in this world, nothing can be said to be certain, except death and taxes!"). 
reporting requirements, as Form 990s are required for 501(c)(3) organizations, but only for those that exceed $\$ 50,000$ in revenues annually. ${ }^{159}$ Plenty of ESOs come short of this threshold, and plenty more PTAs and booster clubs do, too.

While forty-four states required financial reporting from school districts as of 1996, there is reason to think those sorts of reports do not capture the financial activity of outside ESOs. ${ }^{160}$ Making matters worse, it appears that schools have motivation to be discrete about private donations received-districts are only required to report "known" sources of income, and including private donations in that information would likely result in decreased public funding. ${ }^{161}$ Lastly, if a school is able to close a budgetary shortfall using private fundraising, this could create a perverse incentive for the state or the district to underfund that school the following year. If private fundraising fills the gaps left by state funding, then the state and the district may feel less of an obligation to use their resources to solve budget shortfalls in the future, instead relying on the school's ability to address its own budget problems using private donations.

\section{B. The Trouble with Prohibiting Private Donations}

The solution to this dilemma is not as simple as banning private donations to public schools, because private donations to public schools is not a straightforward narrative about wealthy children getting more extravagant schools. And, beyond the consideration that public schools chronically lack sufficient resources, voluntary financial contributions go hand-in-hand with other academic success factors that are not purely financial. Additionally, it can be difficult to draw the line between what is financial and what is not.

As mentioned above, narratives that private donations are by the rich people, for the rich people, are overly simplistic. A parent's desire to contribute discretionary income toward their child's education transcends socioeconomic status, and in that case, it is "absurd to make the argument that parents shouldn't be able to give their kids as much

159. Nelson \& Gazley, supra note 32, at 553-54 \& n.11 (explaining the IRS filing requirement increases to Form 990 , from annual gross receipts of $\$ 25,000$ or more and assets of $\$ 1,250,000$ or more in 2009 , to $\$ 50,000$ in receipts or $\$ 500,000$ in assets in 2010).

160. Rossmiller, supra note 93 , at 24 .

161. Id. 
as they possibly can," however much that might be. ${ }^{162}$ ESOs can serve an important role in protecting parental autonomy for all income levels, giving all parents a way to support their child's education beyond traditional, state-mandated amounts and methods. And, although the current socioeconomic distribution of ESOs is troubling, eliminating them for that reason stops ESOs just as they are figuring out how to come into new, needier communities. ESOs themselves are conscientious of their current inequitable distribution and are encouraging schools and districts to take leading roles in founding these organizations themselves - meaning that burden need not fall entirely on parents without the time or resources to do so. ${ }^{163}$

Next, in financial terms, it is difficult to square a complete prohibition on private donations with the economic reality that states regularly fail to fund education fully. It is defensible to conclude that a state, unable to fund education fully, is in no position to refuse private donations, and that private donations are "a gift horse that does not require dental examination." 164 Further, private donors mean well. Financially supporting education is "acting on noble and wholesome impulses, which public policy should generally encourage." 165 And, if the prohibition of donations boils down to a bleak financial future for public schools, middle- and upper-class parents may be more likely to "just send their kids to private schools and take their ball and go home." 166 This option leaves the schools with less money and leaves public entities with fewer community members holding them

162. Erin McIntyre, Should Private Funding Be Allowed in Public Schools?, EDUCATIONDIVE (May 27, 2016), http://www.educationdive.com/news/should-private-fundingbe-allowed-in-public-schools/419978 [https://perma.cc/57PF-WSW8].

163. Raphael \& Anderson, supra note 118, at 9 (describing school principals and superintendents as important influences in building a successful LEF); Jenkins \& McAdams, supra note 126, at 139, 152-53 ("[A]rgu[ing] that school districts should, in fact, play a far more proactive role in evaluating their private donations," and observing that divided leadership in the San Diego school district, demonstrated by its failure to form an LEF, weakened education reform efforts).

164. Felix Salmon, Why Charitable Donations to Public Schools Are OK, ReUTERs BLOG (Sept. 6, 2013), http://blogs.reuters.com/felix-salmon/2013/09/06/why-charitable-donations-topublic-schools-are-ok [https://perma.cc/F296-NSFL].

165. KAHLENBERG, supra note 71 , at 81.

166. Rich, supra note 106. For additional support for this assertion, see BROWN, SARGRAD \& BENNER, supra note 114, at 11 (explaining that after a school district in Santa Monica, California, implemented redistributive policies, "some parents were angry that they did not have control over their private donations and warned they would be less likely to donate in the future"). 
accountable. Simply leaving the public school system is also not an option that many middle- and lower-class families have. ${ }^{167}$

And focusing myopically on funding equality is shortsighted. If detaching the wealth of a community from the quality of education requires truncating voluntary community support for schools, then the fallout from an exodus of middle- and upper-class families from the public school system would also have nonfinancial ramifications. Middle-class community norms encourage active, multifaceted support of education, manifested in volunteer hours and participation in school governance. ${ }^{168}$ These sorts of efforts benefit the school community as a whole,${ }^{169}$ despite the "psychological reality" that parents may primarily be motivated by a desire to help their own children. ${ }^{170}$ The potential removal of this normative influence is concerning, because there is a growing body of evidence suggesting that successful academic outcomes depend as much on the community's support for education as they do on funding. ${ }^{171}$ These arguments are buttressed by findings related to what has been called "x-efficiency," the "unmeasured and often unobserved school practices and organizational characteristics" 172 that have just as much, if not more, impact on academic outcomes. Signs point to community and parent involvement, both inside and outside the four walls of the school, as a critical indicator of academic success. ${ }^{173}$

Lastly, private donations continue-and even increase-in the face of economic recessions, and there is reason to believe that such donations are not sensitive to changes in tax incentives or, for that matter, policies that limit the inequitable impacts of private donations. ${ }^{174}$ Simply put, decisions to donate to local schools are more about a desire to "give their kids as much as they possibly can,"175 and

167. Id.

168. KAHLENBERG, supra note 71 , at 81.

169. Id.

170. STARK, supra note 143 , at 69.

171. Id.

172. Addonizio, supra note 116 , at 5-7.

173. Id.

174. Rob Reich, A Failure of Philanthropy, 3 Stan. Soc. Innovation ReV. 24, 32 (2005) (suggesting that donations to educational institutions and hospitals are more susceptible to changes in the tax code than religious donations, but noting that donors with income of $\$ 50,000$ or less often are not motivated by tax incentives in the first place).

175. McIntyre, supra note 162. 
less about rich people with "extra" money trying to provide exclusive opportunities to their children.

\section{Appropriate Solutions Require Compromise}

First, a compromise is likely more politically feasible than a solution that completely vindicates one side and completely defeats the other. ${ }^{176}$ Second, even the most vocal proponents of regulating private donation do not suggest that the best solution is blanket prohibition. ${ }^{177}$ Most advocates recognize that parental financial contribution to schools is "inevitable" to a certain extent and is even rooted in admirable and desirable community support for education. ${ }^{178}$ It seems injudicious to conclude that either side is thoroughly wrong or thoroughly right. ${ }^{179}$ As noted above, school administrators like Crew and Fariña, may well find themselves troubled by the equitable principles on both sides, despite their expertise in education finance.

Finally, having rejected the equally inappropriate solutions of flat bans on private donations and freely permitting private donations leads to the conclusion that successful solutions will be a compromise developed according to what each state thinks achieves the best balance of the values at stake: fairness, transparency, community engagement, accountability, and maintenance of high-quality education. ${ }^{180}$

\section{SUGGESTED SOLUTIONS}

To stay true to states' hard-fought historical efforts to provide fair funding for public education, state legislatures can no longer ignore the

176. For a further discussion of the importance of compromise to achieving meaningful substantive change and political feasibility, see infra notes 181-182 and accompanying text.

177. STARK, supra note 143, at 68, Reich, Philanthropy, supra note 33, at 45.

178. See, e.g., STARK, supra note 143, at 68 ("Surely, of the two, it is better that parents raise money for the district than not at all.").

179. To illustrate the idea that reasonable people are found on both sides of these arguments, Laurence Tribe worked with Tristan Duncan representing the plaintiffs in Petrella v. Brownback, Telephone Interview with Tristan Duncan, supra note 56, while his previous legal work suggests that he is an unlikely ally in Ms. Duncan's work. See Tim Wu, Did Laurence Tribe Sell Out?, NEW YORKER (May 6, 2015), https://www.newyorker.com/news/news-desk/did-laurence-tribe-sell-out [https://perma.cc/K4W5-Y2R8] (noting Tribe's past representation of liberal causes stand in apparent conflict to his recent advocacy of more conservative causes).

180. Other scholars have articulated similar frameworks, suggesting that the values of equity, adequacy, efficiency, and choice "compete with one another" but "cannot be given equal weight" because "an answer to one will influence the answer to another." C. PHILLIP KEARNEY \& Michael F. Addonizio, A PRiMER On MichigAn SCHOOL FinANCE 64-65 (4th ed. 2002). 
implications of private donations. In addressing private donations, state legislatures must calibrate an appropriate compromise between unregulated private donations and prohibitions against private donations. Such a compromise would be unnecessary if there were "simply" sufficient public funding for all schools. But that scenario is unlikely, and perhaps impossible, so this Part reviews solutions that attempt to balance the values surrounding the debate about private donations. It concludes that regulations about how donated funds can be used and total caps on donations are unlikely to address the concerns on both sides of the debate, but that strategies like partial caps and luxury taxes are promising, albeit imperfect, steps in the right direction.

A solution that represents some sort of compromise is essential. School districts that have successfully enacted policies to address the equitable concerns about donations have expressed that the most workable solutions can be described as a "marriage of tensions"; that is, solutions that build in values from both sides, and ultimately leave each side neither completely satisfied, nor completely dissatisfied. ${ }^{181}$ Compromise also offers the best chance that a solution is politically feasible. Some might argue that more politically feasible solutions are less likely to make meaningful progress in addressing equality concerns but, for various reasons, bolder solutions are much less likely to make political progress in the first place. ${ }^{182}$ To that end, several solutions represent feasible ways to leave most constituents partially encouraged and partially disappointed.

One possible compromise is permitting private donations to pay for certain parts of public schooling but not others. Some school districts have attempted to offset the potentially unequal effects by distinguishing between core and noncore items of educational funding, prohibiting parental financial support for the former but not the latter. ${ }^{183}$ While this sort of approach successfully addresses concerns about private funds distorting a school's ability to offer core academic

181. STARK, supra note 143 , at 69.

182. Professor Lemos touches on this phenomenon, observing that in the context of statutory interpretation, "[t]he features that make methodology most law-like-its facial neutrality and its generality - may also, paradoxically, enhance its value as a political tool." Margaret H. Lemos, The Politics of Statutory Interpretation, 89 NOTRE DAME L. REV. 849, 854 (2013) (reviewing ANTONIN SCALIA \& BRYAN A. GARNER, READING LAW: THE INTERPRETATION OF LEGAL TEXTS (2012)). This observation easily carries into the argument that a more facially neutral proposition is more politically feasible.

183. Hartocollis, supra note 19, at A1. 
services, the line between core and noncore is not a bright one. Would a capital expenditure for a new classroom building be core? What about Photoshop software or 3D printers? With that approach, it is easy to give a core expenditure a noncore-sounding label. For example, a biology teaching assistant might easily be recast as a "biology consultant." 184 To sidestep drawing this line, some schools instead prohibit donations to support programs that only benefit one class or one grade, but permit donations to support schoolwide programs. ${ }^{185}$ This approach avoids intraschool inequity, and addresses the equitable concerns stemming from a donor's ability to exercise control over such donated funds, but it does not address concerns about inequality between schools in the same district or state.

Turning next to statewide spending or donation caps, such solutions are appealing because they are simple, but they are unlikely to address the goals of compromise, political feasibility, and fair funding, for the same reason. For example, one approach has been to refuse donations, for any purpose or amount, which undermine a school district's authority or educational mission. ${ }^{186}$ Such a malleable standard may be flexible enough to result in fair funding, but this malleability creates uncertainty for potential donors who may prefer to understand the rules for making donations ahead of time. As another approach, some school districts require school board approval for, or flat-out do not accept, donations over a certain amount-though at least one school district policy does not require reporting for gifts under $\$ 50,000 .{ }^{187}$ But it is difficult to set, and easy to criticize, a simple cap to apply to each school's unique economy.

184. See, e.g., Susan Riddell, The Place To Be, KY. TCHR., Sept. 2010, at 7, 7 https://dspace.kdla.ky.gov/xmlui/bitstream/handle/10602/11230/Sept10KyT.pdf?sequence=1 [https://perma.cc/R9E9-YS2W].

185. See, e.g., S.D. CODIFIED LAWS § 13-14-13 (2017) (indicating that none of the ESO-type "funds may be used for capital acquisition, debt retirement, or ordinary expenditures or expenses"). For other examples of schools limiting donations that benefit only one class or grade, see supra note 22 and accompanying text.

186. See, e.g., TENN. CODE ANN. § 49-2-604 (West 2017) (requiring that "the fundraising process [be] consistent with the goals and mission of the school or school district"). It is not clear what would make a process inconsistent with such goals, and there does not appear to be case law associated with the statutes.

187. Chi. Bd. of Educ., Chicago Public Schools Policy Manual § 403.3 (2004), http://policy.cps.edu/download.aspx?ID=3 [https://perma.cc/Y8DH-7PKF]. The Montgomery County Board of Education in Maryland also requires approval for projects above $\$ 50,000$, and further prohibits any private money from funding "teachers and other staff members." Bui, supra note 142 . 
A more effective approach may be one step away from total caps. Partial caps appear to be successful policy choices for school districts and ESOs that have taken initiative to account for the inequitable implications of private donations. ${ }^{188}$ To address concerns that some communities have better access to these donations than others, once donations reach a certain threshold, a percentage of the donation is sent to the state level to support schools with fewer resources. ${ }^{189}$ This sort of compromise maintains parental and local enthusiasm to financially support their schools and encourages the kind of grassroots support that is critical to community engagement in local government.

Similarly, it may be effective to implement a "luxury tax" 190 on schools that receive donations exceeding a statewide threshold. Schools may collect donations beyond that level, but it would be taxed at a "steeply graduated rate," and the excess funds would be redistributed to other schools in the state that are unable to fundraise to that level. ${ }^{191}$ Because this approach, like partial caps, indicates a maximum above which some sort of redistributive principle applies, its results are similar. It may have a rhetorical advantage that partial caps lack, because it does not purport to limit the donation in any way, improving its political feasibility. Measures to control spending are "more effective if [they] take[] the form of taxation rather than an absolute prohibition of luxury spending." 192

Professional athletics may lend surprising insight in this area. ${ }^{193}$ Major League Baseball implemented a luxury tax for teams that pay salaries exceeding a certain threshold, reasoning that it fosters fairer

188. STARK, supra note 143, at 69 (referring to Portland's rule that 33 percent of a school's donations are sent back to the districtwide fund as a "marriage of tensions . . . equity folks say it's too little; some parents say it's too much"); see also Kevin Lynch \& Amy Carlsen Kohnstamm, Portland Public Schools: School Equity? There's More to That Story, OREGONIAN, Oct. 5, 2006, at B7 (describing the success of the Portland Schools Foundation's fundraising effort and its distribution of funds aimed at closing the achievement gap).

189. For additional arguments that partial caps are better than total caps as a solution to inequitable private donations, see Schomberg, supra note 119, at 172-73. Schomberg's suggestion is also noted in YUDOF ET AL., supra note 10, at 875-76.

190. "Luxury," for reference, has been defined "as something that some people think other people should do without." Norman B. Ture, Social Policy and Excise Taxes, 40 TAX NOTES 737, 739 (1988) (quoting Henry C. Simons).

191. Reynolds, supra note 145 , at 812 .

192. Id.

193. Jeffrey D. Van Volkenburg, What Public Education Should Learn from Major League Baseball: Spending Caps, Luxury Taxes and Fiscal Accountability, 32 T. MARSHALL L. REV. 237, 240-41 (2007). 
competition. ${ }^{194}$ Other leagues like the National Basketball Association have followed suit and have apparently achieved greater success in promoting competition using a two-pronged approach that combines a salary cap with a luxury tax. ${ }^{195}$ Because many states use combined methodologies in their funding formulas already, perhaps a combined approach to private donations could work well in an educational context too.

Although partial caps and luxury taxes have the political advantage of reduced transparency, likely making it easier to gain legislative approval, there are drawbacks. Neither the luxury tax nor the "salary cap" approach does much to address concerns related to private donations sidestepping the political process. If parents can still raise unlimited funds outside the public sphere, it likely reduces incentives to pressure state governments to raise the standards for education across the board. These strategies also do little in the way of preventing states from counting on schools and districts to backfill insufficient state funds with donated funds. And, these solutions may not yield immediate significant decreases in school funding inequality. But taking a step toward fairness by way of partial caps or luxury taxes is better than nothing. More effective, but politically infeasible, options may as well be "nothing."

At a minimum, states could start by gathering more information. A preliminary step in the right direction would be to require additional reporting and transparency for private donations. ${ }^{196}$ Currently, 501(c)(3) entities do not have to report at a federal level unless their revenues exceed $\$ 50,000$. All states seem to provide tax incentives for organizations defined similarly, if not exactly the same, as 501(c)(3). ${ }^{197}$ Although as of 2006, school districts are required to report any

194. William B. Gould IV, Labor Issues in Professional Sports: Reflections on Baseball, Labor, and Antitrust Law, 15 STAN. L. \& POL'Y ReV. 61, 77 (2004). See generally Kristi Dosh, Note, Can Money Still Buy the Postseason in Major League Baseball? A 10-Year Retrospective on Revenue Sharing and the Luxury Tax, 3 U. DENV. SPORTS \& ENT. L.J. 1 (2007) (providing a history of Major League Baseball's luxury tax).

195. Gould, supra note 194, at 93; Richard A. Kaplan, Note, The NBA Luxury Tax Model: A Misguided Regulatory Regime, 104 COLUM. L. REV. 1615, 1617 (2004).

196. Michael F. Addonizio, Salvaging Fiscal Control: New Sources of Local Revenue for Public Schools, in BALANCING LOCAL CONTROL AND STATE RESPONSIBILITY FOR K-12 EDUCATION 245, 258 (Neil D. Theobald \& Betty Malen eds., 2000).

197. John D. Colombo, Why is Harvard Tax-Exempt? (And Other Mysteries of Tax Exemption for Private Educational Institutions), 35 ARIZ. L. REV. 841, 855-56 (1993); see also W. HARRISON WELlFORD \& JANNE G. GALlaGHER, UNFAIR COMPETITION?: THE CHALLENGE TO CHARITABle TAX EXEMPTION (1988) (containing a survey of state tax exemptions for charities). 
contributions and donations from private sources for federal census purposes ${ }^{198}$ there do not appear to be uniform efforts for this kind of reporting on a state level. ${ }^{199}$ This suggestion provides maximum political feasibility because it would merely tinker with the reporting ceiling, and decisions about paper pushing are less emotionally fraught. It takes a direct step only in the direction of transparency and a more indirect step toward fairness, but it does not seem to change incentives for community engagement one way or the other. Further, it does not appear to impact existing school funding gaps in education directly, though public disclosure may well be an effective tool to encourage more fortunate schools or districts to voluntarily redirect some of their donated funds to schools with fewer resources. Overall, the only clearly incorrect solution is no solution at all. While partial caps or luxury taxes appear to offer more advantages than total caps and restrictions on donations' uses, any of the presented strategies, or combinations thereof, are worth consideration by state legislatures.

\section{CONCLUSION}

More than thirty years into a substantial increase in ESOs contributing private funds to public education, there is a pressing need for state legislatures to articulate a coherent regime for private donations to public schools. While there is not yet substantial data assessing whether private donations augment inequality, there is reason to suppose this data may someday exist due to the unprecedented growth in ESOs and financial pressures resulting from the 2008 financial recession that are not accounted for in previous studies. Further, ESOs appear to correlate with traditional links between the wealth of a community and the quality of its education, which is a link that state governments have long been attempting to sever. A careful legislative solution requires dutiful acknowledgement of the values animating each side of the debate and achieves a calibrated compromise.

198. Nelson \& Gazley, supra note 32, at 552.

199. Several states require separate accounting for public and private funds in some fashion. See Ala. Code $\S 16-13 A-6$ (2017); Fla. STAT. AnN. § 1011.765 (West 2017); GA. CoMP. R. \& REGS. 560-12-2-.79 (2017); KAN. STAT. ANN. § 12-1663 (West 2017); LA. STAT. ANN. § 17:414.3 (2017); S.C. CODE ANN. § 59-29-510 (2017); VA. CODE ANN. § 22.1-112 (West 2017); WASH. ADMIN. CODE 392-138-017 (2017); WYO. STAT. ANN. § 21-13-310 (West 2017). Some statutes do specifically mention the segregation of donated funds, however, they do not expressly invoke equitable concerns. The District of Columbia, though not included in this survey, also requires reporting of private donations. D.C. CODE ANN. § 38-121.01 (West 2017). 
Appendix A. Existing Regulatory and Statutory Mentions of Private Donations

\begin{tabular}{|c|c|c|c|c|}
\hline \multirow{2}{*}{ State } & \multicolumn{5}{|c|}{ Regulatory or Statutory Mention of Donations: } \\
\cline { 2 - 5 } & ESOs & State Level & Local Level & $\begin{array}{c}\text { School } \\
\text { Level }\end{array}$ \\
\hline Alabama & & $\mathrm{X}$ & $\mathrm{X}$ & $\mathrm{X}$ \\
\hline Alaska & & $\mathrm{X}$ & $\mathrm{X}$ & \\
\hline Arizona & & $\mathrm{X}$ & $\mathrm{X}$ & \\
\hline Arkansas & & $\mathrm{X}$ & $\mathrm{X}$ & \\
\hline California & & $\mathrm{X}$ & $\mathrm{X}$ & \\
\hline Colorado & $\mathrm{X}$ & $\mathrm{X}$ & $\mathrm{X}$ & $\mathrm{X}$ \\
\hline Connecticut & & $\mathrm{X}$ & $\mathrm{X}$ & \\
\hline Delaware & & $\mathrm{X}$ & $\mathrm{X}$ & $\mathrm{X}$ \\
\hline Florida & $\mathrm{X}$ & $\mathrm{X}$ & $\mathrm{X}$ & \\
\hline Georgia & & $\mathrm{X}$ & $\mathrm{X}$ & \\
\hline Hawaii & & $\mathrm{X}$ & & \\
\hline Idaho & & $\mathrm{X}$ & & \\
\hline Illinois & & $\mathrm{X}$ & $\mathrm{X}$ & $\mathrm{X}$ \\
\hline Indiana & $\mathrm{X}$ & $\mathrm{X}$ & $\mathrm{X}$ & $\mathrm{X}$ \\
\hline Iowa & $\mathrm{X}$ & $\mathrm{X}$ & $\mathrm{X}$ & $\mathrm{X}$ \\
\hline Kansas & $\mathrm{X}$ & $\mathrm{X}$ & $\mathrm{X}$ & \\
\hline Kentucky & & $\mathrm{X}$ & $\mathrm{X}$ & $\mathrm{X}$ \\
\hline Louisiana & $\mathrm{X}$ & $\mathrm{X}$ & $\mathrm{X}$ & \\
\hline Maine & $\mathrm{X}$ & $\mathrm{X}$ & $\mathrm{X}$ & $\mathrm{X}$ \\
\hline Maryland & & $\mathrm{X}$ & $\mathrm{X}$ & \\
\hline Massachusetts & & $\mathrm{X}$ & $\mathrm{X}$ & $\mathrm{X}$ \\
\hline Michigan & & $\mathrm{X}$ & $\mathrm{X}$ & $\mathrm{X}$ \\
\hline Minnesota & & $\mathrm{X}$ & $\mathrm{X}$ & \\
\hline Mississippi & $\mathrm{X}$ & $\mathrm{X}$ & $\mathrm{X}$ & $\mathrm{X}$ \\
\hline Missouri & $\mathrm{X}$ & $\mathrm{X}$ & & $\mathrm{X}$ \\
\hline Montana & & $\mathrm{X}$ & $\mathrm{X}$ & \\
\hline Nebraska & & $\mathrm{X}$ & $\mathrm{X}$ & \\
\hline & & & & \\
\hline
\end{tabular}




\begin{tabular}{|c|c|c|c|c|}
\hline \multirow{2}{*}{ State } & \multicolumn{4}{|c|}{ Regulatory or Statutory Mention of Donations: } \\
\cline { 2 - 5 } & ESOs & State Level & Local Level & $\begin{array}{c}\text { School } \\
\text { Level }\end{array}$ \\
\hline Nevada & $\mathrm{X}$ & $\mathrm{X}$ & $\mathrm{X}$ & $\mathrm{X}$ \\
\hline $\begin{array}{c}\text { New } \\
\text { Hampshire }\end{array}$ & & $\mathrm{X}$ & $\mathrm{X}$ & $\mathrm{X}$ \\
\hline New Jersey & $\mathrm{X}$ & $\mathrm{X}$ & $\mathrm{X}$ & \\
\hline New Mexico & $\mathrm{X}$ & $\mathrm{X}$ & $\mathrm{X}$ & \\
\hline New York & & & $\mathrm{X}$ & $\mathrm{X}$ \\
\hline North Carolina & $\mathrm{X}$ & $\mathrm{X}$ & $\mathrm{X}$ & \\
\hline North Dakota & $\mathrm{X}$ & $\mathrm{X}$ & $\mathrm{X}$ & \\
\hline Ohio & $\mathrm{X}$ & & $\mathrm{X}$ & $\mathrm{X}$ \\
\hline Oklahoma & $\mathrm{X}$ & $\mathrm{X}$ & $\mathrm{X}$ & \\
\hline Oregon & & $\mathrm{X}$ & $\mathrm{X}$ & \\
\hline Pennsylvania & & & $\mathrm{X}$ & \\
\hline Rhode Island & & $\mathrm{X}$ & $\mathrm{X}$ & \\
\hline South Carolina & & $\mathrm{X}$ & $\mathrm{X}$ & \\
\hline South Dakota & $\mathrm{X}$ & & $\mathrm{X}$ & $\mathrm{X}$ \\
\hline Tennessee & $\mathrm{X}$ & $\mathrm{X}$ & $\mathrm{X}$ & $\mathrm{X}$ \\
\hline Texas & & $\mathrm{X}$ & $\mathrm{X}$ & $\mathrm{X}$ \\
\hline Utah & $\mathrm{X}$ & $\mathrm{X}$ & $\mathrm{X}$ & \\
\hline Vermont & & & & $\mathrm{X}$ \\
\hline Virginia & $\mathrm{X}$ & $\mathrm{X}$ & $\mathrm{X}$ & \\
\hline Washington & & $\mathrm{X}$ & $\mathrm{X}$ & \\
\hline West Virginia & $\mathrm{X}$ & $\mathrm{X}$ & $\mathrm{X}$ & \\
\hline Wisconsin & $\mathrm{X}$ & $\mathrm{X}$ & $\mathrm{X}$ & \\
\hline Wyoming & & $\mathrm{X}$ & $\mathrm{X}$ & \\
\hline TOTAL & 22 & 45 & 46 & 20 \\
\hline
\end{tabular}




\section{Appendix B. Statutory Discussion of Other Private Donations to Public Education}

As of December 2016, no state had explicitly addressed inequity related to ESO funding. Several states have gone to some lengths to address other education-related donations:

\begin{tabular}{|c|c|}
\hline tit. & $\begin{array}{l}\text { "A musk ox may be loaned or donated to a public institution } \\
\text { for scientific and educational purposes under terms } \\
\text { approved by the commissioner and under guidelines } \\
\text { approved by the board." }\end{array}$ \\
\hline $\begin{array}{r}\text { CAL. CODE } \\
14, \S 40\end{array}$ & $\begin{array}{l}\text { "[G]overnment accredited schools that are open to the } \\
\text { public may possess, accept donations of ... native reptiles } \\
\text { and amphibians without a permit." }\end{array}$ \\
\hline $\begin{array}{l}\text { CAL. EDUC } \\
32390(\mathrm{~W}\end{array}$ & $\begin{array}{l}\text { In a program for fingerprinting kindergartners, "[t]he } \\
\text { governing board may seek to obtain private funding and } \\
\text { volunteer assistance in performing the fingerprinting." }\end{array}$ \\
\hline $\begin{array}{c}\text { KAN. STAT. ANN. } § 72- \\
\text { 64b01 (2002) }\end{array}$ & $\begin{array}{l}\text { "No school district shall expend . . . moneys . . . for . . } \\
\text { litigation . . . against the state of Kansas . . . concerning } \\
\text { school finance. No such moneys shall be paid, donated or } \\
\text { otherwise provided ... and used for the purpose of any such } \\
\text { litigation." }\end{array}$ \\
\hline $\begin{array}{r}\text { LA R.S. } 17: 3 \\
\text { (West } 20\end{array}$ & $\begin{array}{l}\text { "[A]ny person teaching in a Montessori school who receives } \\
\text { a salary paid by the government of France may receive } \\
\text { additional compensation ... whether such funds are part of } \\
\text { its normal operating budget ... or any local, state, or federal } \\
\text { educational organization or foundation." }\end{array}$ \\
\hline $\begin{array}{l}\text { NeV. Admin. CodE } \S \\
503.460(2017)\end{array}$ & $\begin{array}{l}\text { "An owner of a raptor that dies may, without limitation ... } \\
\text { [d]onate the body of the raptor to any person authorized by } \\
\text { permit to acquire and possess the body of a raptor .... If a } \\
\text { taxidermist mounts the raptor: (a) The mount may be used } \\
\text { in a conservation education program." }\end{array}$ \\
\hline $\begin{array}{l}\text { N.H. ReV. STAT. ANN. } \\
\text { § 200:54 (Lexis Cum. } \\
\text { Supp. 2016) } \\
\end{array}$ & $\begin{array}{l}\text { "A school district may accept gifts, grants or donations from } \\
\text { foundations, organizations, or private parties to purchase } \\
\text { bronchodilators, spacers, or nebulizers." }\end{array}$ \\
\hline $\begin{array}{l}\text { N.H. REV. STAT. AN } \\
\S 189: 17 \text {-a (Lexis } 201\end{array}$ & $\begin{array}{l}\text { "The local school board shall have the authority to accept } \\
\text { the donation of flags and appliances, and to determine the } \\
\text { location of the flags in the classrooms." }\end{array}$ \\
\hline
\end{tabular}




\begin{tabular}{|c|c|}
\hline $\begin{array}{l}\text { OKLA. STAT. AnN. tit. } \\
\text { 70, } \S 1210.200 \text { (West } \\
\text { Cum. Supp. 2017) }\end{array}$ & $\begin{array}{l}\text { "Contingent upon the availability of federal funding or } \\
\text { donations from private organizations or persons made for } \\
\text { this purpose, each school district shall make automated } \\
\text { external defibrillators ... available at each school...." }\end{array}$ \\
\hline $\begin{array}{l}\text { OR. ADMIN. R. 635- } \\
\text { 002-0014 (2017) }\end{array}$ & $\begin{array}{l}\text { "Antlers that come into the department's possession shall } \\
\text { be . . . [d] onated to nonprofit organizations, federal } \\
\text { agencies, or Oregon cities, counties or state agencies for any } \\
\text { purpose . . . consistent with the agency's mission including } \\
\text { wildlife-related fundraising .... A nonprofit organization is: } \\
\text { (A) An Oregon public elementary, middle or high school." }\end{array}$ \\
\hline $\begin{array}{l}\text { S.C. Code AnN. REGS. } \\
\text { 123-170 (Cum. Supp. } \\
\text { 2016) }\end{array}$ & $\begin{array}{l}\text { "A falconer may donate the body or feathers of any other } \\
\text { species of falconry raptor ... . He or she may keep ... or } \\
\text { may have the body mounted by a taxidermist. He or she may } \\
\text { use the mount in giving conservation education programs." }\end{array}$ \\
\hline $\begin{array}{l}\text { TEX. EdUC. CODE } \\
\text { ANN. } § 38.017 \text { (West. } \\
\text { Comm. Supp. 2016) }\end{array}$ & $\begin{array}{l}\text { "A school district may seek and accept gifts, grants, or other } \\
\text { donations to pay the district's cost of purchasing automated } \\
\text { external defibrillators ...." }\end{array}$ \\
\hline $\begin{array}{r}31 \text { TEX. AD } \\
\S 65 \\
\end{array}$ & $\begin{array}{l}\text { "Breeder deer may be disposed of by ... sale or donation to } \\
\text { the holder of an educational display permit ...." }\end{array}$ \\
\hline $\begin{array}{l}\text { UTAH ADMIN. CODE r. } \\
\text { R657-20-27 (2017) }\end{array}$ & $\begin{array}{l}\text { "The body or feathers of any other species of falconry } \\
\text { raptor may be donated ... . kept ... or ... mounted by a } \\
\text { taxidermist. (A) The mounted raptor may be used in } \\
\text { conservation education programs... . The body and } \\
\text { feathers of a deceased falconry raptor that are not donated } \\
\text { or retained must be burned, buried, or otherwise destroyed } \\
\text { within } 10 \text { calendar days of the death of the bird or after final } \\
\text { examination by a veterinarian to determine cause of death." }\end{array}$ \\
\hline $\begin{array}{l}\text { VT. STATE. ANN. tit. } 10 \\
\text { app. } § 11(2017)\end{array}$ & $\begin{array}{l}\text { "[A] wild falconry raptor captured in Vermont that is } \\
\text { incapable of surviving for an extended period in the } \\
\text { wild ... }[\mathrm{M}] \text { ay be euthanized in a manner that minimizes } \\
\text { pain and stress, and the carcass disposed of either by } \\
\text { donation to a public scientific or educational organization } \\
\text { permitted to receive wild animals..." }\end{array}$ \\
\hline $\begin{array}{l}\text { WASH. ADMIN. CODE } \\
\text { 220-420-380 (2017) }\end{array}$ & $\begin{array}{l}\text { "The body or feathers of any other species of raptor may be } \\
\text { donated.... The body of any raptor, except that of a golden } \\
\text { eagle (Aquila chrysaetos), may be . . . mounted by a } \\
\text { taxidermist. The mount may be displayed in giving } \\
\text { education programs." }\end{array}$ \\
\hline
\end{tabular}


Appendix C. Statutory Citations Underlying Appendix A Data

\begin{tabular}{|c|c|c|c|c|}
\hline \multirow[b]{2}{*}{ State } & \multicolumn{4}{|c|}{ Regulatory or Statutory Mention of Donations: } \\
\hline & ESOs & State Level & Local Level & $\begin{array}{c}\text { School } \\
\text { Level }\end{array}$ \\
\hline $\mathrm{AL}$ & & $\begin{array}{c}\text { ALA. CODE } \$ \S 16- \\
\text { 3-30, -31 (Lexis } \\
\text { 2012); ALA. } \\
\text { ADMIN. CODE r. } \\
\text { 290-080-092-.04 }\end{array}$ & $\begin{array}{c}\text { ALA. CODE } \S \S 16-8-12,13-36, \\
\text {-13-32 (Lexis 2012) }\end{array}$ & \begin{tabular}{|c|} 
ALA. CODE \\
$\S 16-3-29$ \\
(Lexis \\
2012 )
\end{tabular} \\
\hline AK & & $\begin{array}{l}\text { ALASKA STAT. } \\
\text { ANN. } § 14.07 .030 \\
(\text { Lexis 2016) }\end{array}$ & $\begin{array}{l}\text { ALASKA STAT. ANN. } \S \\
43.23 .062 \text { (Lexis 2016) }\end{array}$ & \\
\hline $\mathrm{AZ}$ & & $\begin{array}{l}\text { ARIZ. REV. STAT. } \\
\text { ANN. } \$ \S 15-204,- \\
\text { 211, -212, -2042 } \\
\text { (West 2014) }\end{array}$ & $\begin{array}{c}\text { ARIZ. REV. STAT. ANN. } \$ \S 15- \\
1154,-1224,-2041 \text { (West } \\
2014 \text { ) }\end{array}$ & \\
\hline $\mathrm{AR}$ & & \begin{tabular}{|l} 
ARK. CODE ANN. \\
$\S \S$ 6-16-303, 20-706 \\
(Lexis 2013)
\end{tabular} & $\begin{array}{c}\text { ARK. CODE ANN. } \S \S 6-13- \\
\text { 1002, -20-417, -21-101, -21-503 } \\
\text { (Lexis 2013); 5.4.17 ARK. } \\
\text { CODE R. } \$ 7\end{array}$ & \\
\hline $\mathrm{CA}$ & & \begin{tabular}{|c|} 
CAL. EDUC. CODE \\
$\S 33332$ (West \\
$2009)$
\end{tabular} & $\begin{array}{c}\text { CAL. EDUC. CODE } \S 41032 \\
\text { (West 2009); CAL. CODE } \\
\text { REGS. tit. 2, } \$ 1800 ; \text { tit. } 5, \S \\
3000\end{array}$ & \\
\hline $\mathrm{CO}$ & \begin{tabular}{|c|}
1 COLO. \\
CODE REGS. \\
$\S 301-$ \\
$11: 2245-\mathrm{R}-$ \\
3.00 (Lexis \\
2017 )
\end{tabular} & $\begin{array}{c}\text { COLO. REV. STAT. } \\
\text { ANN. } \$ \$ 17-32-107, \\
\text { 22-2-138, 22-11- } \\
605,22-37-107,22- \\
80-103 \text { (Lexis 2017) }\end{array}$ & $\begin{array}{c}\text { COLO. REV. STAT. ANN. § 22- } \\
\text { 28-111.5, -32-142, -81.5-105 } \\
\text { (Lexis 2017) }\end{array}$ & $\begin{array}{c}\text { COLO. } \\
\text { REV. STAT. } \\
\text { ANN. } ~ 25- \\
20.5-503 \\
\text { (Lexis } \\
2017) ; 1 \\
\text { COLO. } \\
\text { CODE } \\
\text { REGS. } \\
301- \\
44: 2202-R- \\
4.00 \text { (Lexis } \\
2017 \text { ) }\end{array}$ \\
\hline CT & & $\begin{array}{l}\text { CONN. GEN. STAT. } \\
\text { ANN. } § 10-4 \mathrm{u},-9,- \\
\text { 10d, -11, -76c, -299 } \\
\text { (West 2010) }\end{array}$ & $\begin{array}{l}\text { CONN. GEN. STAT. ANN. § 10- } \\
\text { 21c, -237, -266x (West 2010) }\end{array}$ & \\
\hline
\end{tabular}




\begin{tabular}{|c|c|c|c|c|}
\hline \multirow[b]{2}{*}{ State } & \multicolumn{4}{|c|}{ Regulatory or Statutory Mention of Donations: } \\
\hline & ESOs & State Level & Local Level & $\begin{array}{l}\text { School } \\
\text { Level }\end{array}$ \\
\hline $\mathrm{DE}$ & & $\begin{array}{l}\text { DEL. CODE ANN. } \\
\text { tit. } 14, \S 132 \\
\text { (Michie 2015) }\end{array}$ & $\begin{array}{c}\text { DEL. CoDE ANN. tit. } 14, \S \S \\
1056,4204\end{array}$ & \begin{tabular}{|c}
$14-100$ \\
DEL. \\
ADMIN. \\
CODE $\S$ \\
$101 ;$ \\
DEL. CODE \\
ANN. tit. \\
$14, \S 2302$ \\
\end{tabular} \\
\hline FL & \begin{tabular}{|c|} 
FLA. STAT. \\
ANN. § \\
215.981 \\
(West 2016); \\
§ 1011.765 \\
(West 2013) \\
\end{tabular} & $\begin{array}{l}\text { FLA. ADMIN. CODE } \\
\text { ANN. r. 6A-16.026 }\end{array}$ & $\begin{array}{l}\text { FlA. STAT. ANN. } \$ 11001.43 \\
\text { (West 2016), } 1011.07 \text { (West } \\
\text { 2016), 1101.19 (West 2013); } \\
\text { FLA. ADMIN. CODE ANN. r. } \\
\text { 6A-1.0143 }\end{array}$ & \\
\hline GA & & \begin{tabular}{|c|} 
GA. CONST. art. \\
VIII, § 2, II I; GA. \\
CODE ANN. §§ 20- \\
2-14, -2-67, -2-1070, \\
-14-26.1 (Lexis \\
2016); § 15-21-177 \\
(Lexis 2015) \\
\end{tabular} & $\begin{array}{l}\text { GA. CONST. art. VIII, } \S 5, \mathbb{I} \\
\text { VI; GA. CoDE ANN. } \S \S 20-2- \\
\text { 64, -74, -171, -520, -1075 } \\
\text { (Lexis 2016) }\end{array}$ & \\
\hline $\mathrm{HI}$ & & $\begin{array}{c}\text { HAw. REV. STAT. } \\
\text { ANN. } \$ 302 \text { A-803, } \\
\text { 302A-806, 302A- } \\
\text { 1122, 302A-1148, } \\
\text { 302A-1503, 302L-5, } \\
\text { 321-52 (Lexis } \\
\text { 2013); HAW. CoDE } \\
\text { R. 8-45-1, -46-1, 46- } \\
\text { 2, 46-3, -54-2.6 }\end{array}$ & & \\
\hline ID & & \begin{tabular}{|c|} 
IDAHO CONST. \\
ART. IX, $\$ 4 ;$ \\
IDAHO CODE ANN. \\
$\S \S 33-128,-902,-$ \\
$3408,-3714,-5504 \mathrm{~B}$ \\
(Michie 2015); $\S$ \\
67-824 (Michie \\
2014) \\
\end{tabular} & & $\begin{array}{l}\text { IDAHO } \\
\text { CODE ANN. } \\
\S \S 33-5003 \text {, } \\
-5004 \\
\text { (Michie } \\
\text { 2015) }\end{array}$ \\
\hline
\end{tabular}




\begin{tabular}{|c|c|c|c|c|}
\hline \multirow[b]{2}{*}{ State } & \multicolumn{4}{|c|}{ Regulatory or Statutory Mention of Donations: } \\
\hline & ESOs & State Level & Local Level & $\begin{array}{l}\text { School } \\
\text { Level }\end{array}$ \\
\hline IL & & \begin{tabular}{|c|} 
ILL. ADMIN. CODE \\
tit. $89, \S 830.100$ \\
(2017); ILL. COMP. \\
STAT. ANN. tit. 30, \\
105/6z-46, 215/1 \\
(West 2002); tit. \\
105, 5/2-3.127a, 5/2- \\
3.36, 305/4 (West \\
2002)
\end{tabular} & $\begin{array}{c}105 \text { ILL. COMP. STAT. ANN. } \\
\text { 5/1B-8, 5/5-21, 5/16-1, 5/16-7, } \\
\text { 60/90 (West 2002) }\end{array}$ & $\begin{array}{c}\text { ILL. } \\
\text { ADMIN. } \\
\text { CODE tit. } \\
89,830.20\end{array}$ \\
\hline IN & \begin{tabular}{|c|} 
IND. CODE \\
ANN. $\S \S 20-$ \\
$26-5-22.5,-$ \\
$26-7-9,-47-1-$ \\
5 (Lexis \\
$2015)$ \\
\end{tabular} & $\begin{array}{c}\text { IND. CODE ANN. } \S \\
\text { 20-19-3-5 (Lexis } \\
\text { 2015) }\end{array}$ & $\begin{array}{l}\text { IND. CODE ANN. § 20-35-4-7 } \\
\text { (Lexis 2015) }\end{array}$ & \begin{tabular}{|c|} 
IND. CODE \\
ANN. $\S ~ 20-$ \\
$21-3-11,-$ \\
$22-3-11$ \\
(Lexis \\
2015 ) \\
\end{tabular} \\
\hline IA & $\begin{array}{l}\text { IOWA CODE } \\
\text { ANN. § } \\
279.62(\text { West } \\
\text { 2011) }\end{array}$ & \begin{tabular}{|} 
IOWA CODE ANN. \\
$\S \S 256.36 ;$ \\
$279.51,565.3$ (West \\
$2011)$
\end{tabular} & $\begin{array}{c}\text { IOWA CODE ANN. } \$ 279.42 \\
\text { (West 2011); Iowa Admin. } \\
\text { Code r. 281-98.92 } \\
(257,279,298 \mathrm{~A}, 565), 281- \\
98.67(257,279,298 \mathrm{~A}, 565), 281- \\
98.66(257,279,298 \mathrm{~A}, 565) \\
\end{array}$ & $\begin{array}{c}\text { IOWA } \\
\text { CODE ANN. } \\
\S \text { 298A.15 } \\
\text { (West } \\
\text { 2011) }\end{array}$ \\
\hline $\mathrm{KS}$ & $\begin{array}{l}\text { KAN. STAT. } \\
\text { ANN. \& 72- } \\
8257 \text { (Fuse } \\
2002)\end{array}$ & $\begin{array}{l}\text { KAN. STAT. ANN. } \\
\S \S 72-7518,-7518 \mathrm{a} \\
\quad \text { (Furse 2002) }\end{array}$ & $\begin{array}{l}\text { KAN. ADMIN. REGS. § 91-26-5 } \\
\text { (2017) }\end{array}$ & \\
\hline KY & & $\begin{array}{l}\text { KY. REV. STAT. } \\
\text { ANN. } \$ \S 157.220, \\
157.922,160.580, \\
164.787 \text { (West } \\
\text { 2006) }\end{array}$ & $\begin{array}{c}\text { KY. REV. STAT. ANN. } \S \S \\
156.035,158.867 \text { (West 2006) }\end{array}$ & $\begin{array}{l}\text { Ky. REV. } \\
\text { STAT. ANN. } \\
\text { § } 158.6485 \\
\text { (West } \\
\text { 2006) }\end{array}$ \\
\hline LA & $\begin{array}{c}\text { LA. STAT. } \\
\text { ANN. } \$ 4: 707 \\
\text { (West 2011) }\end{array}$ & \begin{tabular}{|c|} 
LA. STAT. ANN. $\S \S$ \\
17:17.2, :194, :1989. \\
5 (West 2013)
\end{tabular} & $\begin{array}{c}\text { LA. STAT. ANN. § } \\
17: 7,: 81,: 95,: 1757 \text { (West } \\
\text { 2013) }\end{array}$ & \\
\hline $\mathrm{ME}$ & $\begin{array}{l}\text { ME. REV. } \\
\text { STAT. tit. 20- } \\
\text { A, } \S 8202 ; \\
\text { tit. } 30-\mathrm{A}, \S \\
\quad 5652\end{array}$ & 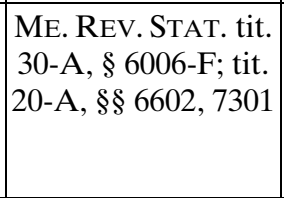 & $\begin{array}{l}\text { ME. REV. STAT. tit. 20-A, } \S \S \\
\text { 1256, 1705, 6213 }\end{array}$ & $\begin{array}{l}\text { ME. REV. } \\
\text { STAT. tit. } \\
20-A, \S \\
7407\end{array}$ \\
\hline $\mathrm{MD}$ & & $\begin{array}{l}\text { MD. CODE ANN. } \\
\text { EDUC. } \$ 2-207 \\
\text { (Lexis 2014) } \\
\end{array}$ & $\begin{array}{c}\text { MD. CODE ANN. EDUC. } \$ 4- \\
118 \text { (Lexis 2014); MD. CoDE } \\
\text { REGS. 23.03.05.05 }\end{array}$ & \\
\hline
\end{tabular}




\begin{tabular}{|c|c|c|c|c|}
\hline \multirow[b]{2}{*}{ State } & \multicolumn{4}{|c|}{ Regulatory or Statutory Mention of Donations: } \\
\hline & ESOs & State Level & Local Level & $\begin{array}{c}\text { School } \\
\text { Level }\end{array}$ \\
\hline MA & & $\begin{array}{l}\text { MASS. GEN. LAwS } \\
\text { ANN. ch. 29, } \S \\
\text { 2MMM (Lexis } \\
\text { 2016) }\end{array}$ & $\begin{array}{l}\text { MASs. GEN. LAWS ANN. ch. } \\
\text { 71, § 37A (Lexis 2013); ch. 60, } \\
\text { § 3C (Lexis 2010); ch. 40, §§ } \\
\text { 3, 4E (Lexis 2006); ch. 44, § } \\
\text { 53A (Lexis 2006); 603 MAss. } \\
\text { CODE REGS. } 50.07\end{array}$ & $\begin{array}{l}\text { MASS. GEN. } \\
\text { LAWS ANN. } \\
\text { ch. } 76, \S \\
12 \mathrm{~A}\end{array}$ \\
\hline MI & & $\begin{array}{c}\text { Mich. COMP. LAWS } \\
\text { ANN. } \\
\S \S 388.1008, .1008 \mathrm{a} \\
\text { (Thomson 2014); } \\
\S \S 12.262,21.161 \\
\text { (West 2004) }\end{array}$ & $\begin{array}{c}\text { MicH. COMP. LAWs ANN. } \S \\
\text { 380.11a, .602, .402, .431a } \\
\text { (West 2014); } \$ 380.15 \text { (West } \\
\text { 2013) }\end{array}$ & $\begin{array}{l}\text { MicH. } \\
\text { COMP. } \\
\text { LAWS ANN. } \\
\S 380.1311 \mathrm{~h} \\
\text { (West } \\
2013)\end{array}$ \\
\hline $\mathrm{MN}$ & & $\begin{array}{c}\text { MinN. STAT. ANN. } \\
\S 16 \text { A.013 } \\
\text { (Thomson 2013); } \\
\S \S 127 \text { A.32, } \\
\text { 124D.118 } \\
\text { (Thomson 2016) }\end{array}$ & $\begin{array}{l}\text { MinN. STAT. ANN. } \S \S 465.03 \text {, } \\
\text { 471.69 (Thomson West 2008) }\end{array}$ & \\
\hline MS & $\begin{array}{l}\text { Miss. CoDE. } \\
\text { ANN. \& 37- } \\
11-73 \text { (Lexis } \\
\text { 2013) }\end{array}$ & \begin{tabular}{|c|} 
Miss. CODE. ANN. \\
$\S 37-11-8$ (Lexis \\
2013 )
\end{tabular} & $\begin{array}{l}\text { Miss. CODE. ANN. \$§ 37-7- } \\
\text { 301, -419 (Lexis 2013) }\end{array}$ & $\begin{array}{c}\text { Miss. } \\
\text { CODE. } \\
\text { ANN. § 37- } \\
139-11,- \\
140-11 \\
\text { (Lexis } \\
2013 \text { ) }\end{array}$ \\
\hline MO & $\begin{array}{l}\text { Mo. AnN. } \\
\text { STAT. } \S \\
167.280 \\
\text { (West 2010) }\end{array}$ & $\begin{array}{l}\text { Mo. CONST. art. } \\
\text { IX, } \S 5 ; \text { Mo. ANN. } \\
\text { STAT. } \S \S 160.925, \\
\text { 161.930, 162.785, } \\
\text { 162.790, 166.101 } \\
\text { (West 2010) }\end{array}$ & & $\begin{array}{l}\text { Mo. CoDE } \\
\text { REGS. ANN. } \\
\text { tit. } 12, \S 10- \\
42.030\end{array}$ \\
\hline MT & & \begin{tabular}{|c|} 
MONT. CODE ANN. \\
$\S \S 20-8-111,-9-601$, \\
$-9-604,-9-905,17-3-$ \\
1001 (2014); MONT. \\
ADMIN. R. \\
10.59.101
\end{tabular} & $\begin{array}{c}\text { MoNT. CODE ANN. } \S \S 20-3- \\
\text { 208, -6-601, -9-604, -10-201 } \\
(2014)\end{array}$ & \\
\hline $\mathrm{NE}$ & & \begin{tabular}{|c|} 
NEB. REV. STAT. \\
ANN. $§ 17-162$ \\
(Lexis 2017); $\S \S 72-$ \\
266, 79-1063, 79- \\
1104.02 (Lexis \\
2014)
\end{tabular} & $\begin{array}{l}\text { NEB. REV. STAT. ANN. § 79- } \\
1204 \text { (Lexis 2014) }\end{array}$ & \\
\hline
\end{tabular}




\begin{tabular}{|c|c|c|c|c|}
\hline \multirow[b]{2}{*}{ State } & \multicolumn{4}{|c|}{ Regulatory or Statutory Mention of Donations: } \\
\hline & ESOs & State Level & Local Level & $\begin{array}{c}\text { School } \\
\text { Level }\end{array}$ \\
\hline NV & $\begin{array}{c}\text { NEV. REV. } \\
\text { STAT. ANN. } \\
\S \S 388 D .270 \text {, } \\
.280 \text { (Lexis } \\
\text { 2016) }\end{array}$ & \begin{tabular}{|l} 
NEV. REV. STAT. \\
ANN. $\S \$ 388.800$, \\
385.083, 391A.255 \\
(Lexis 2016)
\end{tabular} & \begin{tabular}{|c|} 
NEV. REV. STAT. ANN. $\S$ \\
354.598005 (Lexis 2017); $\S \S$ \\
$386.390,387.090,387.175$, \\
$388.453,389.064$ (Lexis 2016)
\end{tabular} & $\begin{array}{l}\text { NEV. REV. } \\
\text { STAT. ANN. } \\
\text { § 388G.210 }\end{array}$ \\
\hline $\mathrm{NH}$ & & \begin{tabular}{|} 
N.H. REV. STAT. \\
ANN. § 195-J:3 \\
(Lexis 2011); N.H. \\
CODE R. ED 905.04
\end{tabular} & $\begin{array}{c}\text { N.H. REV. STAT. ANN. § 31:19 } \\
\text { (Lexis 2013); }\end{array}$ & \begin{tabular}{|c} 
N.H. REV. \\
STAT. ANN. \\
§ 194-D:5 \\
(Lexis \\
2011)
\end{tabular} \\
\hline NJ & $\begin{array}{c}2016 \mathrm{NJ} \\
\text { Regulation } \\
\text { Text } 21410 \\
\text { (Sept. 18, } \\
\text { 2017) } \\
\end{array}$ & \begin{tabular}{|l} 
N.J. STAT. ANN. $\S \S$ \\
18A: 4-26, :7G-22, \\
$: 20-4,: 51-7,: 56-1$ \\
(West 2010)
\end{tabular} & $\begin{array}{l}\text { N.J. STAT. ANN. § 18A:18A- } \\
15.1 \text { (West 2010); } \\
\text { N.J. ADMIN. CoDE §§ 6A:26- } \\
3.12, .15\end{array}$ & \\
\hline $\mathrm{NM}$ & $\begin{array}{l}\text { N.M. STAT. } \\
\text { ANN. } § 6- \\
\text { 5A-1 (2013) }\end{array}$ & \begin{tabular}{|c|} 
N.M. STAT. ANN. \\
$\S \S 22-2 \mathrm{C}-9,22-2 \mathrm{C}-$ \\
$10,22-8-47,22-8-$ \\
$48,22-9-4,22-13-$ \\
$28.1,22-15 \mathrm{E}-6$, \\
$32 \mathrm{~A}-23-8,32 \mathrm{~A}-$ \\
$23 \mathrm{~A}-5(2017)$ \\
\end{tabular} & $\begin{array}{l}\text { N.M. STAT. ANN. § 22-5-4 } \\
\text { (2017) }\end{array}$ & \\
\hline NY & & & \begin{tabular}{|c|} 
N.Y. EDUC. LAw $\S \S 1950$, \\
2590-m (Thomson 2007); \\
N.Y. PuB. AUTH. LAW $§ 1689$
\end{tabular} & $\begin{array}{c}\text { N.Y. EDUC. } \\
\text { LAw § 3701 } \\
\text { (Thomson } \\
\text { 2015); } \\
\text { § 4318 } \\
\text { (Thomson } \\
\text { 2016) }\end{array}$ \\
\hline $\mathrm{NC}$ & $\begin{array}{c}\text { N.C. GEN. } \\
\text { STAT. ANN. } \\
\S \S 115 \text { C-490, } \\
-491,-492 \\
\text { (West 2010) }\end{array}$ & $\begin{array}{l}\text { H.B. 17D, } 2016 \\
\text { Gen. Assemb., } \\
\text { Extra Sess. (N.C. } \\
\text { 2015); N.C. GEN. } \\
\text { STAT. ANN. \$\$ } \\
\text { 115C-410, 116C-5 } \\
\text { (West 2010) }\end{array}$ & $\begin{array}{c}\text { N.C. GEN. STAT. ANN. } \S \S \\
\text { 115C-47, -238.65 (West 2010) }\end{array}$ & \\
\hline ND & $\begin{array}{l}\text { N.D. CENT. } \\
\text { CODE ANN. } \\
\S 21-06-12 \\
\text { (Lexis 2012) } \\
\end{array}$ & $\begin{array}{l}\text { N.D. CENT. CODE } \\
\text { ANN. } \S \$ 1-08-02,4- \\
\text { 37-04 (Lexis 2012) }\end{array}$ & $\begin{array}{c}\text { N.D. CENT. CODE ANN. §§ 1- } \\
\text { 08-04, 15.1-09-51, 15.1-35-04 } \\
\text { (Lexis 2015) }\end{array}$ & \\
\hline
\end{tabular}




\begin{tabular}{|c|c|c|c|c|}
\hline \multirow[b]{2}{*}{ State } & \multicolumn{4}{|c|}{ Regulatory or Statutory Mention of Donations: } \\
\hline & ESOs & State Level & Local Level & $\begin{array}{c}\text { School } \\
\text { Level }\end{array}$ \\
\hline $\mathrm{OH}$ & $\begin{array}{c}\text { OHIO REV. } \\
\text { CODE ANN. } \\
\S \\
2921.43(\mathrm{~A}) \\
(1)\end{array}$ & & $\begin{array}{c}\text { OHIO REV. CODE ANN. } \S \S \\
\text { 3302.067, 3313.36, 3313.17, } \\
3315.40 \text { (West 2012); } \$ 307.22 \\
\text { (West 2005); OHIO ADMIN. } \\
\text { CODE 3301-51-02 }\end{array}$ & $\begin{array}{l}\text { OHio REv. } \\
\text { CODE ANN. } \\
\S \S 3325.10 \text {, } \\
.15(\text { West } \\
2012) \\
\end{array}$ \\
\hline OK & $\begin{array}{l}\text { OKLA. STAT. } \\
\text { ANN. tit. 70, } \\
\S 5-145 \\
\text { (Thomson } \\
\text { 2013) }\end{array}$ & \begin{tabular}{|} 
OKLA. STAT. ANN. \\
tit. $70, \S \S 622$, \\
$1210.227,1210.257$, \\
1210.555 (Thomson \\
2005)
\end{tabular} & $\begin{array}{l}\text { OKLA. STAT. ANN. tit. 70, } \S 3- \\
\text { 129.5 (Thomson 2013); tit. 11, } \\
\S 22-125 \text { (West 2012); tit. 60, } \\
\text { 381 (West 2010); tit. 70, } \S \\
\text { 1210.710 (Thomson 2005) }\end{array}$ & \\
\hline OR & & \begin{tabular}{|c|} 
OR. CONST. art. \\
VIII, $\$ 2 ;$ OR. REV. \\
STAT. ANN. $\S$ \\
$327.008,327.344$ \\
$342.953,346.270$ \\
$(2015)$
\end{tabular} & $\begin{array}{c}\text { OR. REV. STAT. ANN. } \S \S \\
\text { 328.105, 328.155, 334.215 } \\
\text { (2015); OR. ADMIN. R. 581- } \\
\text { 024-0310 }\end{array}$ & \\
\hline PA & & & $\begin{array}{l}24 \text { PA. STAT. ANN. § 2-216 } \\
\text { (Thomson 2016) }\end{array}$ & \\
\hline RI & & $\begin{array}{l}\text { R.I. CONST. art. } \\
\quad \text { XII, } \S 3\end{array}$ & $\begin{array}{c}\text { 16 R.I. GEN. LAwS ANN. } \S \\
\text { 16-3-11, -19-1.1, -89-5 (Lexis } \\
\text { 2013); §§ 16-89-2, -4 (Lexis } \\
\text { 2010); tit. 45, § 45-38-3 (Lexis } \\
\text { 2010) }\end{array}$ & \\
\hline $\mathrm{SC}$ & & \begin{tabular}{|c|} 
S.C. CODE ANN. $\S \S$ \\
$59-29-440,-69-40$, \\
$-152-50,-152-130$ \\
(Thomson 2004)
\end{tabular} & $\begin{array}{c}\text { S.C. CODE ANN. \$§ 59-19-160, } \\
\text {-33-60, -65-280 (Thomson } \\
2004)\end{array}$ & \\
\hline SD & $\begin{array}{c}\text { S.D. } \\
\text { CODIFIED } \\
\text { LAws } \$ 13- \\
14-13 \text { to }-14 \\
\text { (Thomson } \\
\text { 2004) }\end{array}$ & & $\begin{array}{c}\text { S.D. CODIFIED LAWS } \\
\S 13-14-5 \text { (Thomson 2004) }\end{array}$ & \begin{tabular}{|l} 
S.D. \\
CODIFIED \\
LAwS \\
$\S 13-16-1$ \\
(Thomson \\
2004)
\end{tabular} \\
\hline $\mathrm{TN}$ & $\begin{array}{l}\text { TENN. CODE } \\
\text { ANN. } \$ \$ 49- \\
2-602,-603 \text {, } \\
-604,-612 \\
\text { (Lexis 2017) }\end{array}$ & \begin{tabular}{|c|} 
TENN. CODE ANN. \\
$\S \S 49-6-1405,-2006$, \\
-2405 (Lexis 2017)
\end{tabular} & $\begin{array}{c}\text { TENN. CoDE ANN. } \$ 49-16- \\
103 \text { (Lexis 2017) }\end{array}$ & \begin{tabular}{|c|} 
TENN. \\
CODE ANN. \\
$\S 49-2-607$ \\
(Lexis \\
2017) \\
\end{tabular} \\
\hline
\end{tabular}




\begin{tabular}{|c|c|c|c|c|}
\hline \multirow[b]{2}{*}{ State } & \multicolumn{4}{|c|}{ Regulatory or Statutory Mention of Donations: } \\
\hline & ESOs & State Level & Local Level & $\begin{array}{l}\text { School } \\
\text { Level }\end{array}$ \\
\hline $\mathrm{TX}$ & & \begin{tabular}{|c|} 
TEX. EDUC. CODE \\
ANN. $\$ \S 21.453$, \\
$37.214,45.163$ \\
(West 2012)
\end{tabular} & $\begin{array}{c}\text { TEX. Educ. CodE ANN. } \S \S \\
\text { 11.156, 29.915, 38.213, } 45.516 \\
\text { (West 2012); } 19 \text { TEX. ADMIN. } \\
\text { CODE } § 61.1081\end{array}$ & $\begin{array}{c}\text { TEX. EDUC. } \\
\text { CODE AnN. } \\
\S \S 26.67- \\
\text { App., } \\
30.025 \\
30.056 \\
\text { (West } \\
2012)\end{array}$ \\
\hline UT & \begin{tabular}{|c} 
UTAH \\
ADMIN. \\
CODE r. 628- \\
$2-9$
\end{tabular} & $\begin{array}{l}\text { UTAH CODE ANN. } \\
\S \S 53 \mathrm{~A}-1-406,63 \mathrm{~N}- \\
12-205 \text { (Lexis 2016) }\end{array}$ & $\begin{array}{l}\text { UTAH CODE ANN. § 53A-4- } \\
205 \text { (Lexis 2016); § 11-2-8 } \\
\text { (Lexis 2015); UTAH ADMIN. } \\
\text { CODE r. 277-407-5 }\end{array}$ & \\
\hline VT & & & & $\begin{array}{l}\text { VT. STAT. } \\
\text { AnN. tit. } \\
\text { 16, } \$ 3641 \\
\text { (Lexis } \\
2016 \text { ) } \\
\end{array}$ \\
\hline VA & \begin{tabular}{|c} 
VA. CODE \\
ANN. $\$ \S$ \\
$22.1-212.2: 2$, \\
-289.01 \\
(Lexis 2016)
\end{tabular} & \begin{tabular}{|c|} 
VA. CoDE ANN. $\S \S$ \\
$22.1-98.1,-175.2$, \\
$-175.7,-199.4$, \\
$-299.2,318.1$ (Lexis \\
2016); 8 VA. \\
ADMIN. CoDE $\S 20-$ \\
81-100 (Lexis \\
2016); VA. CoDE \\
ANN. $\S 9.1-110$ \\
(Lexis 2012)
\end{tabular} & $\begin{array}{c}\text { VA. CoDE ANN. \$§ 22.1-126, } \\
\text {-353 (Lexis 2016) }\end{array}$ & \\
\hline WA & & \begin{tabular}{|c|} 
WASH. REV. CODE \\
ANN. $\S \S$ \\
28A.300.465, \\
.515 .300 (West \\
2014); $\S 43.215 .450$ \\
(West 2012$) ; \S$ \\
72.40 .300 (West \\
2004) \\
\end{tabular} & $\begin{array}{l}\text { WASH. REV. CODE ANN. } \S \S \\
\text { 28A.193.040, .320.030 (West } \\
\text { 2011) }\end{array}$ & \\
\hline WV & $\begin{array}{l}\text { W. VA. } \\
\text { CODE R. } \S \\
126-2-3\end{array}$ & \begin{tabular}{|} 
W. VA. CONST. art. \\
XII, § 4; W. VA. \\
CODE ANN. § 18-2- \\
16 (Lexis 2016); \\
§ 5B-2C-4 (Lexis \\
2015)
\end{tabular} & $\begin{array}{l}\text { W. VA. CODE ANN. } \S \S 18-5- \\
13,-5 D-4,-9 D-3 \text { (Lexis 2016) }\end{array}$ & \\
\hline
\end{tabular}




\begin{tabular}{|c|c|c|c|c|}
\hline \multirow[b]{2}{*}{ State } & \multicolumn{4}{|c|}{ Regulatory or Statutory Mention of Donations: } \\
\hline & ESOs & State Level & Local Level & $\begin{array}{c}\text { School } \\
\text { Level }\end{array}$ \\
\hline WI & $\begin{array}{c}\text { Wis. STAT. } \\
\text { ANN. § } \\
118.27 \\
\text { (Thomson } \\
2016 \text { ) }\end{array}$ & $\begin{array}{l}\text { WIS. STAT. ANN. } \S \\
\text { 115.29 (Thomson } \\
\text { 2016); WIS. ADMIN. } \\
\text { CODE PI } \S 20.02\end{array}$ & $\begin{array}{l}\text { WIS. STAT. ANN. \& 118.27 } \\
\text { (Thomson 2016) }\end{array}$ & \\
\hline WY & & $\begin{array}{l}\text { WYO. CONST. art. } \\
\text { VII, § 3; WyO. } \\
\text { STAT. ANN. §§ 21- } \\
\text { 2-603; -22-101 } \\
\text { (Lexis 2017) }\end{array}$ & $\begin{array}{c}\text { WYO. STAT. ANN. § 21-20-108 } \\
\text { (Lexis 2017); 206-2-8 WyO. } \\
\text { CODE R. § } 4 \text { (Lexis 2017) }\end{array}$ & \\
\hline
\end{tabular}

